\title{
Suvremeno iseljavanje Hrvata u Njemačku: karakteristike i motivi
}

DOI: https://doi.org/10.11567/met.33.3.4 UDK: 314.743(430=163.42)"2017" $331.55(430=163.42) " 2017 "$

Prethodno priopćenje Primljeno: 12.01.2018. Prihvaćeno: 26.02.2018.

\section{Tado Jurić}

Hrvatsko katoličko sveučilište, Zagreb

tado.juric@unicath.hr

\begin{abstract}
SAŽETAK
U radu su predstavljeni rezultati istraživanja motiva i karakteristika novijih iseljavanja Hrvata u Saveznu Republiku Njemačku. Prema percepciji samih iseljenika, glavni motivi iseljavanja nisu ekonomski. Analiza iseljeničkih stavova pokazala je da je glavni poticaj odlasku iz zemlje predodžba da u Hrvatskoj nisu institucionalizirane vrijednosti radne etike i uopće poštenja te iseljenici smatraju da se hrvatsko društvo moralno slomilo. Rad se temelji na istraživanju provedenom u Njemačkoj kombiniranom metodologijom. Podaci su prikupljeni metodama ankete i polustrukturiranog intervjua tijekom 2017., na uzorku od 1200 Hrvata iseljenih u Njemačku. Kao polazište u analizama su upotrijebljeni i službeni hrvatski i njemački statistički podaci, koji su poslužili kao deskriptivni i komparativni okvir provedene studije. Rezultati istraživanja pokazali su povezanost između političke etike, slabih institucija i iseljavanja. Usto, postojanje razgranatih hrvatskih migrantskih mreža iz prošlosti u Njemačkoj olakšava i potiče migraciju. Broj iseljenih u Njemačku znatno je veći od onoga koji bilježi službena statistika, a osnovni su trendovi iseljavanja sljedeći: većinom se iseljavaju mlade osobe između dvadeset i četrdeset godina, koje su pretežito bile zaposlene te se $\mathrm{u}$ pravilu iseljavaju s cijelim obiteljima. Iseljeni Hrvati svojim su »novim životom « u Njemačkoj u pravilu vrlo zadovoljni i nisu požalili što su se odselili u Njemačku.
\end{abstract}

KLJUČNE RIJEČI: iseljavanje, Hrvati, Hrvatska, Bosna i Hercegovina, Njemačka

\section{UVOD}

Međunarodne migracije nisu interesno neutralne i ne događaju se slučajno, nego se proizvode. One nisu slučajan društveni fenomen (Mesić, 2014: 176). Hrvatska, kao ekonomski i populacijski slabije razvijena zemlja, u globalizacijskim je procesima više izložena moćnim migracijskim silnicama nego što na njih može utjecati, a ulaskom u EU, čija je temeljna vrijednost mobilnost radne snage, njena je pozicija u tome još više oslabjela (Mesić, 
2014: 176). Hrvatska se i prije recentnog vala iseljavanja ubrajala među europske zemlje s najizraženijim i najdugotrajnijim iseljavanjem, uzrokovanim brojnim povijesnim, političkim i ekonomskim okolnostima. Iseljavanje je imalo takve razmjere da se u pojedinim razdobljima više od trećine hrvatskoga naroda nalazilo izvan granica svoje domovine (Čizmić, Sopta i Šakić, 2005: 14).

Tijekom iseljavanja šezdesetih i sedamdesetih godina 20. stoljeća Hrvati su najviše odlazili u SR Njemačku. Godine 1972. radnici s područja bivše SFRJ s brojem od gotovo pola milijuna zauzimali su prvo mjesto među svim skupinama stranih radnika u SR Njemačkoj. ${ }^{1}$ Uračunavši neprijavljene, smatra se da je potkraj osamdesetih njihov ukupni broj iznosio od 650.000 do 700.000. Statistički podaci, iako nisu precizni, pokazuju da je među njima bilo najviše Hrvata (sve do osamostaljenja njemačka službena statistika poznavala je samo Jugoslavene) (Čizmić, Sopta i Šakić, 2005: 232). Prema Popisu stanovništva iz 1971., iz Hrvatske je bilo 196.000 radnika privremeno zaposlenih u europskim državama (Stanković, 1982). Od toga je velika većina bila upravo u Njemačkoj. Istraživanje Instituta društvenih znanosti Ivo Pilar $^{2}$ o povratnicima pokazuje da je petina migrirala zbog političkih razloga, a dvije trećine zbog ekonomskih ili mješavine ekonomskih i političkih. Politički motivi dominirali su u prvome hrvatskom poslijeratnom iseljeničkom valu, a ekonomski od šezdesetih do devedesetih godina (Čizmić, Sopta i Šakić, 2005: 478-479).

Nema sumnje da su i današnje migracije usmjerene ponajprije na Njemačku. ${ }^{3}$ Razlog tomu upravo su velikim dijelom razgranate hrvatske migrantske mreže iz prošlosti u Njemačkoj i tzv. tradicija iseljavanja Hrvata u Njemačku. Naime brojna naselja u Hrvatskoj i BiH imaju više osoba u Njemačkoj nego u matičnim zemljama (usp. Akrap, 1998). Obiteljska, rodbinska i druga posredništva pri iseljavanju imaju veliku ulogu u cijelom fenomenu.

Ulaskom Republike Hrvatske u Europsku uniju 2013. dolazi do pojačanog iseljavanja Hrvata u Njemačku (prvo veliko iseljavanje bilo je tijekom

1 Prema službenom popisu stanovništva iz 1955., u Njemačkoj je bilo 20.553 ljudi iz tadašnje Jugoslavije (Statistisches Jahrbuch der Deutschen Demokratischen Republik, 1955-1989). Nakon sklapanja međudržavnog ugovora između SR Njemačke i SFRJ, kojim su utvrđeni uvjeti zapošljavanja i prava radnika iz Jugoslavije, 1969., zabilježen je nagli porast na 226.290 radnika (Čizmić, Sopta i Šakić, 2005: 232).

2 Istraživanje je provedeno na uzorku iseljenika koji su se nakon 1990. vratili u Hrvatsku (Šakić i sur., 1997).

3 To pokazuju i podaci Državnog zavoda za statistiku prema kojima se od ukupnog broja odseljenih osoba iz Republike Hrvatske tijekom 2016. najviše osoba odselilo u Njemačku (Migracija stanovništva Republike Hrvatske u 2016., 2017). 
šezdesetih i sedamdesetih godina 20 stoljeća, a drugo tijekom Domovinskog rata). Masovno iseljavanje počinje 1. srpnja 2015., kada Njemačka otvara svoje tržište rada za radnike s hrvatskom putovnicom. Hrvatska vlada u to je vrijeme preko službenih kanala EU-a lobirala da Njemačka otvori granice za hrvatske radnike, tj. da ne produlji restrikcije za zapošljavanje hrvatskih državljana. Naime slobodan protok radnika za neke zemlje ne počinje s datumom pristupanja članice Europskoj uniji. Svaka stara članica EU-a ima pravo uvesti restrikcije za zapošljavanje radnika novim članicama do maksimalnih sedam godina. Njemačka je to ograničenje ukinula u srpnju 2015. Pravo na rad u drugoj državi članici EU-a može se ograničiti prijelaznim mjerama najdulje do 30. lipnja 2020. Do sada su prijelazne mjere prema Hrvatskoj zadržale još Austrija, ${ }^{4}$ Slovenija, Velika Britanija, Malta i Nizozemska. ${ }^{5}$

Iako su mnogi predviđali umjeren utjecaj, pokazalo se da je ulazak u Europsku uniju bio značajni moment koji je uklanjanjem barijera mobilnosti stvorio nove perspektive i alternativu i uvelike pospješio odlazak hrvatskog stanovništva u potrazi za boljim životom. Od ulaska u EU vidimo da se iseljavanje svake godine intenziviralo, a da od 2015., 2016. i 2017. naročito raste (detaljni podaci navedeni su u nastavku rada).

Glavni i osnovni cilj istraživanja bio je utvrditi motivaciju Hrvata za iseljavanje u Njemačku. Istraživanjem su obuhvaćeni Hrvati iz Hrvatske i Hrvati iz Bosne i Hercegovine. Zanimalo nas je iseljavaju li se Hrvati zaista samo zbog ekonomskih razloga ili postoje i neki drugi razlozi. Što traže Hrvati u Njemačkoj, a što nisu mogli dobiti u matičnim zemljama? Nakon što smo ustanovili da je više od polovine ispitanika prije iseljavanja bilo zaposleno, nastojali smo doznati glavne motive iseljavanja Hrvata iz Hrvatske i BiH.

Unatoč važnosti fenomena iseljavanja i važnosti koju predstavljaju Hrvati izvan domovine za matičnu domovinu, u Hrvatskoj je danas vrlo malo stručnih i znanstvenih radova ${ }^{6}$ koji se bave najnovijim analizama migracija hrvatskih građana, napose u Njemačku, kamo ih se iselilo najviše. U Bosni i Hercegovini ne postoji nikakav sustav praćenja iseljeničkih tokova niti po-

4 Austrija pak ne primjenjuje privremena ograničenja na samozaposlene osobe iz Hrvatske, što pokazuje izvjesno olakšavanje pristupu austrijskom tržištu rada, koje je uz Njemačku za hrvatske građane među najatraktivnijima. Lider austrijskih socijaldemokrata Christian Kern predviđa da će u vrlo kratkom roku u Austriju doći oko sto pedeset tisuća radnika iz Hrvatske ako Austrija otvori vrata hrvatskim radnicima 1. srpnja 2018. (Bachner, 2018).

5 Prema podacima na internetskoj stranici Europa.eu: https://europa.eu/youreurope/citizens/work/work-abroad/work-permits/index_hr.htm (28.01.2018.).

6 Jedini je izuzetak rad Akrapa, Strmote i Ivande iz 2017., koji na dvije stranice spominje problem iseljavanja Hrvata u Njemačku. 
stoje podaci o povratku iseljenika (Ministarstvo sigurnosti $\mathrm{BiH}, 2016$ ), a migracijske strategije $\mathrm{RH}$ u proteklih deset godina djeluju kao da su prepisane od neke useljeničke zemlje, jer se jedva bave pitanjem iseljavanja.

Pokušali smo saznati i koliko su politički čimbenici važni pri odluci o migraciji te ima li ponašanje političara $u$ matičnim zemljama veze s odlukom o odlasku. Željeli smo saznati kako se hrvatski iseljenici osjećaju, jesu li nostalgični i jesu li požalili što su se odselili.

\section{METODOLOŠKI PRISTUP}

Istraživanje na kojem se temelji ovaj rad provedeno je u Njemačkoj kombinacijom kvalitativne i kvantitativne metode. Od kvantitativnih metoda upotrijebljena je metoda ankete (u kombinaciji s online anketom), a od kvalitativnih metoda polustrukturiranog intervjua. Uz podatke prikupljene terenskim istraživanjem, u radu se analiziraju i službeni hrvatski i njemački statistički podaci. Prikupljanje podataka trajalo je od siječnja do listopada 2017. Prigodni uzorak čini 1200 odraslih ispitanika iseljenih u Njemačku od 2013. do 2017., pri čemu se ispitanicima pristupalo putem mreže hrvatske nastave u Njemačkoj, ${ }^{7}$ mreže hrvatskih katoličkih misija u Njemačkoj ${ }^{8}$ i grupe na Facebooku »Idemo u svijet - Njemačka«. Gotovo tisuću upitnika sakupljeno je online anketom, a dvjesto u pisanom obliku. Upitnik u pisanom obliku pretežito su ispunjavali roditelji učenika koji pohađaju hrvatsku nastavu u SR Njemačkoj u pokrajinama Bayern, Baden-Würtemberg i Hessen (gdje i boravi najveći broj hrvatskih iseljenika). Online anketu ispunjavali su Hrvati diljem Njemačke do kojih smo došli preko više grupa na Facebooku, prije svega grupe »Idemo u svijet - Njemačka«.

Provedeno istraživanje u najvećem je dijelu utemeljeno u teoriji Everetta S. Leeja (1966), prema kojoj se migracije analiziraju u kontekstu potisnih i privlačnih čimbenika te njihovu odnosu. Prema njemu su najvažniji potisni čimbenici koji mogu utjecati na migracije sljedeći: 1) promjene u prirodnoj okolini (npr. zatvaranje neke industrije i sl.) ili prirodne nepogode, poput potresa, poplave, epidemije, 2) ekonomski čimbenici, poput slabe mogućnosti zaposlenja, niskih primanja, loših radnih i životnih uvjeta, 3) politički čimbenici, koji uključuju neslaganje s političkim sustavom, nedostatak osnovnih građanskih sloboda, represije i proganjanja te 4) društveni čim-

7 Vidi npr. Hrvatska nastava u Bavarskoj, http://www.hr-nastava-bavarska.skole.hr/ (28.01.2018.).

8 Autor istraživanja radio je u Hrvatskoj nastavi u SR Njemačkoj pet godina kao koordinator i nastavnik hrvatske nastave u Bavarskoj. Ta institucionalna mreža omogućila je uspostavu kontakata s katoličkim misijama i hrvatskim iseljenicima diljem Njemačke. 
benici, koji se odražavaju u otuđenosti od vlastite zajednice (nemogućnost pripadanja užoj zajednici i identifikacije s njom te osjećaj bespomoćnosti pri realiziranju društvenih ciljeva), nemogućnost napredovanja i usavršavanja znanja. S druge strane, u privlačne čimbenike spadaju: 1) znatno bolje ekonomske mogućnosti (viši životni standard, bolja zarada i mogućnost zaposlenja), 2) mogućnost stjecanja željenog obrazovanja, specijalizacije i sl., 3) prirodna okolina i životni uvjeti, poput klime, stanovanja, škola i ostalih usluga, ali i politički sustav neke zemlje te 4) odlazak za nekim tko nas privlači na bilo kakav način - emigracija se odvija kanalima rodbinstva, susjedstva i prijateljstva.

Navedena je teorija nadopunjena primjenom mikroanalitičkog modela autora Heinza Fassmanna i Christiane Hintermann (1997: 11), koji pokazuju da društveni i profesionalni položaj, motivacija, preferirana odredišta, transnacionalna umreženost prostora podrijetla, migracijska povijest obitelji i oblici društvenih veza potencijalnih migranata čine temeljne varijable odluke o migraciji, odnosno percepcija vlastite situacije i osobna motivacija postaju najvažniji čimbenici.

Provedena anketa sastojala se od nekoliko segmenata: prikupljeni su sociodemografski i socioekonomski podaci o ispitaniku, ispitali su se ispitanikova migracijska povijest, motivacija za preseljenjem, percepcija vrijednosti, zadovoljstvo životom u Njemačkoj i stav prema Njemačkoj i Hrvatskoj, radno iskustvo te planovi. Sve skale i pitanja originalno su izrađeni ili prilagođeni za ovo istraživanje, a u analizama je fokus na opisu stanja i ustanovljavanju moguće povezanosti pojedinih komponenta.

Od specifičnih skala koje su upotrijebljene $u$ istraživanju u nastavku se opisuju one vezane uz vrijednosti sustav, motivaciju za iseljavanje, percepciju situacije u Hrvatskoj te emocionalni doživljaj života u Njemačkoj, koje se detaljnije analiziraju u ovom radu.

Skala kojom se ispitivao vrijednosni sustav ispitanika sastojala se od trinaest čestica, poput: Važno mi je bogatstvo; Važan mi je nacionalni identitet i domovina; Važna mi je profesionalna karijera, na koje su ispitanici odgovarali na skali od 1 (Uopće se ne slažem) do 5 (Potpuno se slažem).

Kao motive iseljavanja ispitanici su procjenjivali primjerice nezaposlenost, niske plaće, korupciju/nepotizam/kriminal te pravnu nesigurnost/nefunkcioniranje institucija (ukupno trinaest motiva). Ispitanici su odgovorima na skali od 1 (Najmanje važno pri odluci) do 5 (Najviše važno pri odluci) procjenjivali važnost svakog od njih.

Skala kojom su se prosuđivali čimbenici koji su imali utjecaj na nastanak današnjih problema $u$ RH, a koji se u radu također analiziraju kao mogući 
motivi iseljavanja iz Hrvatske sastojala se od trinaest indikatora poput: neučinkovitog pravosuđa, komunističkog nasljeđa u glavama ljudi i bankarske pohlepe. Skala je djelomično preuzeta iz istraživanja Vedriš, Letica i Letica, (2012) te je modificirani za potrebe ove studije, a ispitanici su prilikom procjene koristili skalu od 1 (Nema utjecaja) do 5 (Iznimno veliki utjecaj).

Skalom emocionalnog doživljaja života u Njemačkoj putem jedanaest tvrdnji procjenjivalo se osjećaje općenito vezane uz iseljenički život. Tvrdnjama poput »U Njemačkoj se osjećam generalno bolje nego u domovini«, »Osjećam se osamljeno i otuđen« ili »Imam osjećaj da više dobivam u stranoj zemlji nego što gubim u domovini « ispitanici su izražavali stupanj slaganja na skali od 1 (Uopće se ne slažem) do 5 (Potpuno se slažem).

Općenito zadovoljstvo životom u Njemačkoj (uzevši sve aspekte života u obzir) ispitanici su procjenjivali na skali od 1 (Vrlo sam nezadovoljan) do 5 (Vrlo sam zadovoljan).

Kako bi se postignuli postavljeni ciljevi istraživanja, postavljene su sljedeće hipoteze:

1) Nezaposlenost ili nemogućnost pronalaska odgovarajućeg posla $u$ struci u Hrvatskoj i BiH nisu glavni motivi iseljavanja, 2) Najveću sklonost migriranju iskazuju mladi, 3) Najviše iseljenika nije iz regija s najvećim gospodarskim problemima $u$ zemlji, 4) Dominanto obilježje ovog iseljavanja jest iseljavanje cijelih obitelji, 5) Percepcija iseljenika je da se hrvatsko društvo moralno slomilo te 6) Hrvati se u Njemačkoj osjećaju otuđeno te imaju izrazit osjećaj da su stranci.

$\mathrm{U}$ istraživanju je upotrijebljen i kvalitativni pristup jer se na taj način mogu prikupiti specifičnije činjenice koje daju informacije o kontekstu istraživanja te se može dobiti uvid u podatke koje je teško prikupiti anketom. Intervjui su provedeni u Münchenu tijekom proljeća 2017. na uzorku od petnaest novoiseljenih obitelji iz Hrvatske (devet porijeklom iz BiH). Intervju je bio polustrukturiran sa zadanim okvirnim temama razgovora, a ispitanici su birani metodom »snježne grude«. Do sugovornika smo došli putem mreže osobnih poznanstava u Münchenu. Pitanja su bila ista kao i $\mathrm{u}$ anketi, s tim da je naglasak stavljen na njihovu interpretaciju događaja $\mathrm{u}$ domovini i doživljaj života u Njemačkoj.

Osnovni problem s istraživanjem aktualnih migracija Hrvata u Njemač$\mathrm{ku}$ jest taj da nije u potpunosti poznata struktura populacije koja se iselila, pa je samim time nemoguće kreirati reprezentativni uzorak. ${ }^{9}$ Sve dostupne

9 Grizelj i Akrap (2011) pokazuju da je osnovni suvremeni metodološki problem bilježenja vanjskih migracija nepostojeća sustavno vođena statistička baza iz koje bi bilo moguće utvrditi stvarni i precizni broj stalno prisutnoga te useljenoga i iseljenoga stanovništva. 
relevantne procjene polaze od toga da se od ulaska Hrvatske u EU iselilo oko 200.000 hrvatskih građana. Ovaj uzorak od 1200 ispitanika prilično je robustan i svakako može pokazati osnovne tendencije iseljavanja Hrvata, ali zbog specifičnih ograničenja istraživanja ne može biti reprezentativan pa je stoga, uvjetno rečeno, prigodan (reprezentativni uzorak danas još uvijek nitko ne može imati).

\section{SUVREMENE MIGRACIJE U NJEMAČKU}

Točni broj iseljenih iz Hrvatske nije problematično dati samo u promatranom razdoblju. Veliki problem s procjenama migracija kontinuirano se isticao u različitim razdobljima. Nakon što bi došlo do jačeg iseljavanja, uglavnom su se nizale različite procjene broja iseljenih, koje su u pravilu bile nepouzdane. Ne umanjujući vrijednost znanstvenih istraživanja i parcijalnih analiza, priklanjamo se mišljenju Akrapa, Strmote i Ivande (2017) da su jedinu sveobuhvatnu raščlambu iseljavanja iz Hrvatske u prethodnim migracijskim etapama u svim glavnim aspektima do danas dali samo Rogić i Čizmić (2011).

Procjene broja iseljenih iz Hrvatske tijekom najnovijeg iseljavanja iz zemlje temeljimo na podacima Državnoga zavoda za statistiku Republike Hrvatske i Njemačkoga saveznog ureda za statistiku (Destatis). Pritom valja imati u vidu da nije zanemariv broj hrvatskih iseljenika koje ni hrvatska ni njemačka službena statistika nisu registrirale. Takav je pristup ujedno i najveće ograničenje istraživanja migracija, naročito s obzirom na to da prema zakonu osobe koje napuste zemlju moraju o tome obavijestiti Ministarstvo unutarnjih poslova, no budući da se prekršajna odredba u praksi ne provodi, velika većina građana to ne čini. Stoga dolazi do disproporcije stvarnoga stanja iseljenih i hrvatske službene statistike (usp. Akrap, Strmota i Ivanda, 2017: 545).

No svakako je potrebno biti oprezan i u interpretaciji njemačkih demografskih statistika jer je riječ o registru stanovništva prema državljanstvu, pa je nemoguće razdvojiti Hrvate iz Hrvatske od Hrvata iz Bosne i Hercegovine kao vrlo velikoga izvorišta hrvatskih iseljenika, a usto se novorođena djeca automatski smatraju državljanima Njemačke.

Stanovništvo EU-a rođeno u drugim zemljama čini oko deset posto njezina ukupnog stanovništva. Pojedine europske države imaju i znatno viši

Statistika koju vodi Odjel za upravne poslove MUP-a, a koju od njega preuzima Državni zavod za statistiku, nedovoljno je precizna i neujednačena. $S$ tim u vezi nužno je žurno uspostaviti Registar stanovništva. 
postotak svojih stanovnika rođenih negdje drugdje (Irska 14,1\%; Francuska 10,7\%) (Mesić, 2014: 162). Njemačka s više od deset milijuna stranaca prednjači u Europi.

U Njemačkoj je ukupni udio imigranata (zajedno sa stranim radnim migrantima i "povratnicima «, pripadnicima njemačke etničke manjine iz Istočne Europe) u cjelokupnoj populaciji 14\%, čime je prema svim pokazateljima postala tipična useljenička zemlja. U najužem shvaćanju broj stranaca u Njemačkoj iznosi više od deset milijuna (Mehr als 10 Millionen Ausländer in Deutschland, Destatis, 2017), što je ujedno i najveći broj stranaca u jednoj europskoj državi.

Najbrojniji su Turci, kojih je službeno oko 3,5 milijuna (1,35 milijuna bez njemačkog državljanstva), zatim Poljaci (703.080) te Talijani (557.400) (Eurostat, 2016).

Pred ulazak Hrvatske u EU broj Hrvata u Njemačkoj iznosio je uključujući i one s hrvatskim porijeklom ${ }^{10}$ oko 367.000 . Njemački podaci navode 240.543 uoči ulaska u EU (Destatis, 2015). Prema podacima hrvatskih katoličkih misija u Njemačkoj za 2001. godinu, Hrvata je u Njemačkoj bilo 308.337, dok se podaci njemačkih (nad)biskupija neznatno razlikuju. Taj broj obuhvaća sve one koji se izjašnjavaju Hrvatima iz Hrvatske, Bosne i Hercegovine i drugih dijelova bivše SFRJ.

Polegubić (2015: 284) na osnovi podataka župnih knjiga hrvatskih katoličkih misija u Njemačkoj smatra da je u Njemačkoj do 2001. moglo biti između 350.000 i 400.000 Hrvata, unatoč njemačkim statistikama, koje navode oko 220.000. Jer poznato je također da priličan broj Hrvata u Njemačkoj radi »na crno«, a oni se ne vode ni u kakvim statistikama. Pretpostavlja se da je takvih od pedeset do sto tisuća. U statistikama se ne vode ni oni koji imaju dvojno, njemačko ili neko drugo državljanstvo. Problem vođenja statistike također je u tome što od 2000. sva djeca koja se rode u Njemačkoj automatski dobivaju njemačko državljanstvo, a poslije se vode u statistikama njemačkih katoličkih župa i zajednica.

Kada pogledamo podatke Državnog zavoda za statistiku Republike Hrvatske i usporedimo ih s onim iz SR Njemačke, vidimo da su potpuno neusklađeni (tablice $1-4$, slika 1 ).

10 Pojam označuje podrijetlom Hrvate koji iz nekog razloga nemaju hrvatsko državljanstvo. 
Tablica 1. Broj stanovnika doseljenih u Njemačku i odseljenih iz nje 2009. $-2016$.

Table 1. The number of immigrants and emigrants to and from Germany, $2009-2016$

\begin{tabular}{cccc}
\hline & Doseljeni & Odseljeni & $\begin{array}{c}\text { Migracijski } \\
\text { saldo }\end{array}$ \\
\hline 2009. & 733 & 459 & 274 \\
\hline 2010. & 456 & 775 & -319 \\
\hline 2011. & 679 & 1061 & -382 \\
\hline 2012. & 620 & 1883 & -1263 \\
\hline 2013. & 913 & 2193 & -1280 \\
\hline 2014. & 1095 & 7961 & -6866 \\
\hline 2015. & 1770 & 12325 & -10.555 \\
\hline 2016. & 2582 & 20432 & -17.850 \\
\hline
\end{tabular}

Izvor: Statistike u nizu, Migracije, DZS, Zagreb, 2017., https://www.dzs.hr/hro/publication/ firstreleaselfirstrel.asp

Tablica 2. Prijavljeni hrvatski građani u SR Njemačkoj

Table 2. Croatian citizens registered in Germany

\begin{tabular}{ccccccc}
\hline 1994. & 2001. & 2011. & 2013. & 2014. & 2015. & 2016. \\
\hline 176.251 & 223.819 & 220.199 & 240.543 & 263.347 & 297.895 & 332.605 \\
\hline Izvor: Destatis, $h$ htt://wwww.destatis.del
\end{tabular}

Tablica 3. Broj hrvatskih državljana i stanovnika hrvatskog porijekla po saveznim pokrajinama do kraja 2013.

Table 3. The number of Croatian citizens and residents of Croatian descent in German federal provinces by the end of 2013

\begin{tabular}{lcc}
\hline Pokrajina & $\begin{array}{c}\text { Broj hrvatskih } \\
\text { državljana }\end{array}$ & $\begin{array}{c}\text { Procjena broja stanovnika } \\
\text { hrvatskog porijekla }\end{array}$ \\
\hline Baden-Württemberg & 72.986 & 119.000 \\
\hline Bayern & 50.594 & 82.000 \\
\hline Nordrhein-Westfalen & 36.324 & 65.000 \\
\hline Berlin & 9131 & 14.000 \\
\hline Niedersachsen & 6153 & 10.000 \\
\hline Hamburg & 4823 & 11.000 \\
\hline
\end{tabular}


Tablica 4. Brojnost hrvatskih državljana prema saveznim pokrajinama 2014., 2015. i 2016.

Table 4. The number of Croatian citizens in German federal provinces in 2014, 2015 and 2016

\begin{tabular}{lccc}
\hline Pokrajina & $\mathbf{2 0 1 4 .}$ & $\mathbf{2 0 1 5 .}$ & $\mathbf{2 0 1 6 .}$ \\
\hline Baden-Württemberg & 82.092 & 92.092 & 101.595 \\
\hline Bayern & 64.163 & 76.185 & 88.135 \\
\hline Nordrhein-Westfalen & 41.043 & 41.043 & 48.610 \\
\hline Berlin & 9131 & 9526 & 10.130 \\
\hline Niedersachsen & 7429 & 8505 & 9605 \\
\hline Hamburg & 5668 & 5990 & 6320 \\
\hline
\end{tabular}

Izvori: Bevölkerung und Erwerbstätigkeit. Ausländische Bevölkerung. Ergebnisse des Ausländerzentralregisters, Statistisches Bundesamt (Destatis), Wiesbaden, 2015; Bevölkerung und Erwerbstätigkeit. Ausländische Bevölkerung. Ergebnisse des Ausländerzentralregisters, Statistisches Bundesamt (Destatis), Wiesbaden, 2016.

Slika 1. Rasprostranjenost Hrvata u Njemačkoj - udio po okruzima Figure 1. Distribution of Croats in Germany - proportions by county

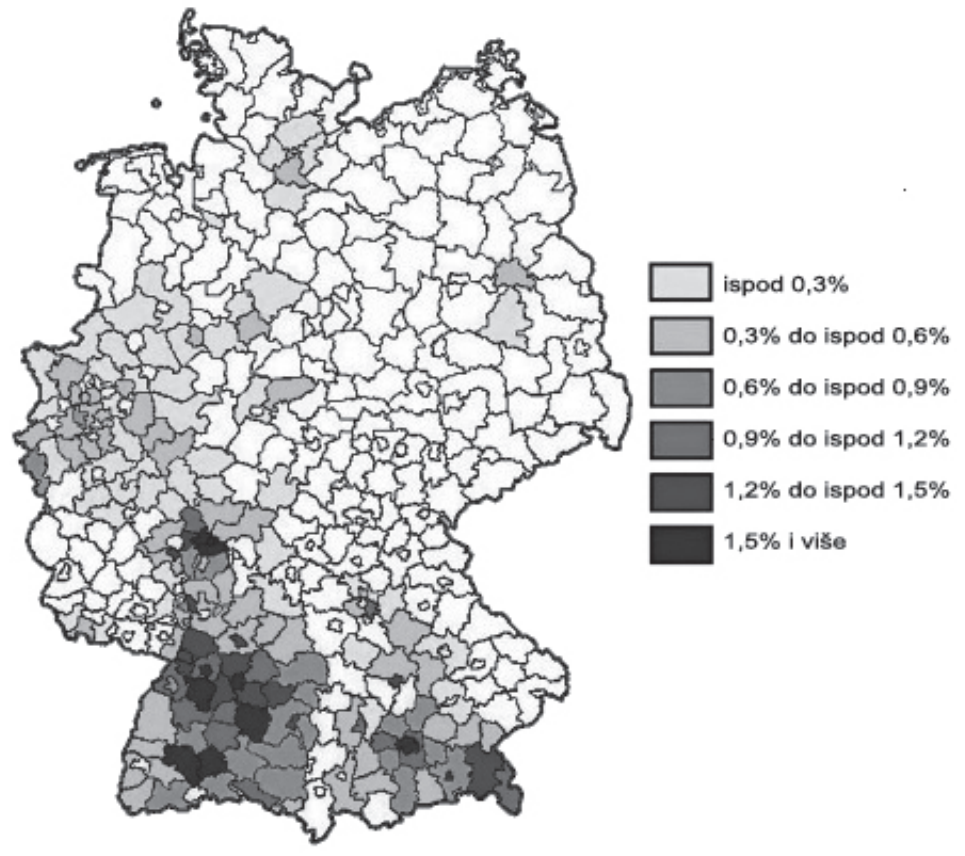

Izvor: Kroaten in Deutschland - Landkreise, Kartenseite, https://kartenseite.wordpress. com/2017/03/26/kroaten-in-deutschland-landkreisel 
Prema podacima Saveznog zavoda za statistiku SR Njemačke, od ulaska Hrvatske u EU do 2017. u Njemačku se doselilo oko 200.000 hrvatskih državljana, od kojih je gotovo 100.000 zaposlenih. Tu činjenicu potkrepljuje i nedavna izjava savezne ministrice SR Njemačke Andree Nahles: »Zahvaljujući olakšicama pri pristupanju tržištu rada, koje primjenjujemo posljednje dvije godine, danas je već 93.000 Hrvatica i Hrvata u Njemačkoj zaposleno uz obavezno socijalno osiguranje, kao npr. u zdravstvu i društvenim djelatnostima ili u prerađivačkom sektoru (Volle Öffnung des Arbeitsmarktes für Kroatien..., 2015).

Broj hrvatskih državljana koji su stekli njemačko državljanstvo naglo je porastao nakon ulaska Hrvatske u Europsku uniju. Tako je primjerice 2014. godine 3889 državljana RH dobilo njemačko državljanstvo, dok je taj broj prije 2013. iznosio oko petsto po godini (M. D., 2017). Hrvati danas u Njemačkoj slove kao jedna od rijetkih etničkih skupina kojoj je njemačko državljanstvo primamljivo. Naime u 2015. godini Hrvati su imali zabilježen dvostruko veći porast prelaska na njemačko državljanstvo nego u prethodnim godinama, dok je kod svih etničkih skupina uočen pad. Svega 2,2\% stranaca u ukupnom broju stranaca koji isu stekli pravo na njemačko državljanstvo to su pravo i iskoristili (Doppelt so viele Kroaten beantragen deutschen Pass, 2015).

Prema dokumentu Freizügigkeitsmonitoring: Migration von EU-Bürgern nach Deutschland (Migracija EU-građana u Njemačku), 2014. u Njemačku se uselilo 37.060 osoba s hrvatskim državljanstvom, 2015. njih 50.628, a 2016. godine 51.163. To je porast od 15\% u odnosu na 2014., no kad taj broj usporedimo godinama prije ulasku u EU, vidimo da je riječ o porastu od više od 300\% (u tom je razdoblju iseljavanje bilo između 10.000 i 13.000 osoba na godišnjoj razini) (Freizügigkeitsmonitoring..., 2017a).

Tablica 5. Iseljenici iz Hrvatske u Njemačku 2010. - 2016.

Table 5. Emigrants from Croatia to Germany 2010 - 2016

\begin{tabular}{lccccccc}
\hline & 2010. & 2011. & 2012. & 2013. & 2014. & 2015. & 2016. \\
\hline $\begin{array}{l}\text { Broj } \\
\begin{array}{l}\text { iseljenika } \\
\text { iz RH }\end{array}\end{array}$ & 4836 & 8089 & 9019 & 18.633 & 37.060 & 50.646 & 51.163 \\
\hline
\end{tabular}

Izvor: Freizügigkeitsmonitoring: Migration von EU-Bürgern nach Deutschland, Jahresbericht 2016, Bundesamt für Migration und Flüchtlinge, Forschungszentrum Migration, Integration und Asyl, Nürnberg, 2017a. 
Tablica 6. Dobna struktura doseljenih hrvatskih državljana u Njemačku 2016.

Table 6. Age structure of Croatian citizens immigrated to Germany in 2016

\begin{tabular}{l|c|c|c|c|c|c|c|c}
\hline Ukupno & $\mathbf{0 - 1 5}$ & $\mathbf{1 6}-\mathbf{1 7}$ & $\mathbf{1 8 - 2 4}$ & $\mathbf{2 5}-\mathbf{3 4}$ & $\mathbf{3 5 - 4 4}$ & $\mathbf{4 5 - 5 4}$ & $\mathbf{5 5 - 6 4}$ & $\begin{array}{c}\mathbf{6 5} \mathrm{i} \\
\text { više }\end{array}$ \\
\hline 51.163 & 7562 & 663 & 8792 & 14.190 & 9905 & 7084 & 2546 & 421 \\
\hline
\end{tabular}

Izvor: Freizügigkeitsmonitoring: Migration von EU-Bürgern nach Deutschland, Jahresbericht 2016, Bundesamt für Migration und Flüchtlinge, Forschungszentrum Migration, Integration und Asyl, Nürnberg, 2017a.

Iz tablica 5 i 6 vidimo da su najbrojniji među iseljenicima hrvatski državljani u dobi između 25 i 44 godina, dok naši podaci još preciznije pokazuju (zbog većeg broja dobnih kategorija) da je riječ o dobi između 20 i 40 godina. U ukupnom kontingentu iseljenih iz Hrvatske (tablica 6) u Njemačku veliki je broj i maloljetne djece, što govori u prilog činjenici da se iseljavaju cijele obitelji.

Istraživanje Peračkovića i Rihtara (2016) pokazalo je da je 2014. u ukupnoj populaciji bilo nešto manje od $15 \%$ onih koji se ozbiljnije namjeravaju iseliti (često razmišljaju o tome ili to ozbiljno planiraju), pri čemu odnos dobi i namjera odlaska nije linearan, tj. nakon navršenih četrdeset godina te namjere naglo slabe. Konkretnije, gotovo trećina (31\%) mlađih (do 40 godina) o odlasku često razmišlja ili ga ozbiljnije planira, dok među starijima (40 i više godina) taj udio pada na $6,2 \%$.

O koristi useljavanja tako mladog stanovništva za Njemačku najbolje govori činjenica kako je u posljednjih pet godina udio visokokvalificiranih radnika među useljenicima iz EU-a jednak udjelu visokokvalificiranih Nijemaca među domaćim stanovništvom (Schellinger, 2015).

\section{STRUKTURNI PROBLEMI}

Iseljavanje, dakako, nije samo jednostavno oduzimanje broja iseljenika od ukupnog broja stanovnika u vremenu iseljenja, već taj fenomen valja promatrati s dugoročnim posljedicama u smjeru poremećaja u dobnom sastavu stanovništva i sužavanja biološke osnovice za obnavljanje stanovništva (Akrap i Strmota, 2015: 71).

Iseljavanje šezdesetih i sedamdesetih godina 20. stoljeća u Njemačku i današnje iseljavanje značajno se razlikuju. U prethodnim razdobljima (šezdesetih i sedamdesetih) nije bilo prirodnog pada u kretanju stanovništva 
Hrvatske, a iseljavanje je uglavnom bilo privremeno, pri čemu nije dolazilo do iseljavanja cijelih obitelji kao danas, već su u migracijama uglavnom sudjelovali muškarci ili parovi bez djece ili parovi koji su djecu ostavljali u Hrvatskoj, obično kod svojih roditelja. Stoga se može očekivati da će recentno iseljavanje iz Hrvatske imati dalekosežne demografske, ekonomske, socijalne i druge posljedice.

U razdoblju SFR Jugoslavije Hrvatska i BiH nisu imale dostatnu autonomiju za oblikovanje i upravljanje društvenim promjenama tijekom iseljavanja šezdesetih i sedamdesetih, ali danas je situacija drugačija, dok su rezultati za najveći dio hrvatskih krajeva podjednako loši. Zašto je tomu tako, pokušat ćemo pokazati u nastavku ovog poglavlja.

Za razliku od prijašnjih iseljavanja glavninu iseljenih sada čine mlađi ljudi s visokom naobrazbom. U hrvatskom društvu njihov je odlazak dvostruki gubitak: smanjuje se demografski potencijal stanovništva te slabe profesionalne skupine sposobne usmjerivati hrvatsko društvo prema modernijem i kvalitetnijemu razvoju (Čipin, 2014). Gospodarske, demografske i socijalne posljedice iseljavanja stanovništva brojne su i imaju dvojak učinak. One ostavljaju posljedice u mjestu podrijetla i u mjestu odredišta, prije svega mijenjajući demografske karakteristike tih područja: veličinu i prostorni razmještaj, fertilitetni potencijal, mortalitet i strukturu stanovništva (Wertheimer-Baletić, 1999). Svako seljenje stanovništva ima dva vremenska učinka: prvi, trenutačni, koji se manifestira samim događajem mijenjajući veličinu stanovništva, prostorni razmještaj i strukturu, i drugi, dugoročni, koji s odgodom odnosi i donosi vitalne događaje (rođenja, smrti, brakove i razvode) (Akrap, Strmota i Ivanda, 2017: 545).

$\mathrm{Na}$ ovaj ili onaj način posljedice iseljavanja iz Hrvatske najbolje se odražavaju na području nacionalnoga gospodarstva (tablica 7). Odlazak na rad u inozemstvo ima dva učinka: prvo, zapošljavanjem u inozemstvu značajno je smanjena potencijalna nezaposlenost $\mathrm{i}$, drugo, dio registriranih nezaposlenih otišao je na rad u inozemstvo (Akrap i Strmota, 2015: 71-79). Stoga je jasno da je iseljavanje pogodovalo statistici nezaposlenih, kojom se nerijetko barata u politikantske svrhe kao relevantnim pokazateljem ekonomskoga razvoja i rasta (Akrap i Strmota, 2015: 71-79). Negativne posljedice snažnoga iseljavanja vidljive su odmah i bez vremenskoga odmaka. One se očituju kroz smanjenu potrošnju i smanjenje ukupne zaposlenosti u zemlji te smanjenje proračunskih prihoda i rashoda zbog pada broja poreznih obveznika i proračunskih korisnika. Kako glavninu iseljenika čini radno aktivno stanovništvo, najveći gubitak imat će prihodna strana proračuna (usp. Akrap, Strmota i Ivanda, 2017: 549). Dodatni je problem i sama struktura 
državnoga proračuna jer većina proračunskih prihoda dolazi od oporezivanja potrošnje (PDV i trošarine), a znatni dio proračunskih rashoda odlazi na mirovine (Ministarstvo financija RH, 2016). To će zasigurno dovesti do još većih pritisaka na mirovinski sustav u Hrvatskoj, uz ionako iznimno nepovoljni omjer aktivnih osiguranika i umirovljenika (usp. Akrap, Strmota i Ivanda, 2017: 549). Omjer radnika i umirovljenika jest 1,16 : 1 (Statističke informacije 2016., 2016). U studiji »Demografski razvoj kao temelj planiranja razvoja mirovinskog sustava « Stjepan Šterc navodi da će uslijed iseljavanja rasti troškovi za zdravstveno osiguranje i njegu, pa će biti nemoguće održati postojeći mirovinski i zdravstveni sustav. Nastavi li se ovakav tempo, Hrvatska će uskoro imati opterećenje od tri neaktivna na jednoga aktivnog osiguranika, što mirovinski sustav, prema prognozi navedene studije, može izdržati još samo pet godina (Šterc, 2017).

Iseljavanje se odražava i na obrazovni sustav u Hrvatskoj. Broj djece u predškolskom odgoju te u osnovnom i srednjoškolskom obrazovanju smanjuje se. Podaci Državnog zavoda za statistiku pokazuju kako se ukupni broj učenika/djece školske dobi u deset godina, od školske godine 2004./2005. (kada ih je bilo 391.112), u školskoj godini 2014./2015. smanjio na 322.998 - za čak 68.114, što je jednako prosječnom broju stanovnika jedne hrvatske županije (Župarić-Iljić, 2016: 10).

Tablica 7. Učinci iseljavanja

Table 7. The effects of emigration

\begin{tabular}{|c|c|c|}
\hline Pozitivni & Negativni & Dvojbeni \\
\hline $\begin{array}{l}\text { - } \text { manja } \\
\text { nezaposlenost u } \\
\text { struci; } \\
\text { - } \text { veće plaće u struci } \\
\text { emigranata; } \\
\text { - doznake iz } \\
\text { inozemstva; } \\
\text { - ljudski i financijski } \\
\text { kapital povratnika }\end{array}$ & $\begin{array}{l}\text { - } \text { »odljev mozgova«, gubitak } \\
\text { - } \text { gubudskoga kapitala (i ulaganja); } \\
\text { emigranata; } \\
\text { - } \text { smanjenje agregatne potražnje; } \\
\text { - } \text { manja ukupna zaposlenost; } \\
\text { - } \text { veća nezaposlenost i manje } \\
\text { plaće komplementarne struke } \\
\text { - } \text { emigranta; } \\
\text { - manja kompetitivnost; } \\
\text { - } \text { iseljavanja produktivnost; } \\
\text { negativno utječe na rast BDP-a }\end{array}$ & $\begin{array}{l}\text { - veća participacija } \\
\text { na tržištu rada } \\
\text { obitelji emigranata } \\
\text { koje ostaju; } \\
\text { - manja participacija } \\
\text { na tržištu rada } \\
\text { obitelji koje } \\
\text { primaju doznake; } \\
\text { - lakša buduća } \\
\text { migracija } \\
\text { stanovništva }\end{array}$ \\
\hline
\end{tabular}

Preuzeto od Akrap, Strmota i Ivanda , 2017, usp. Atoyan i sur., 2016 
S druge strane, problemi koji su doveli do masovnog iseljavanja mladih Hrvata iz BiH nisu vezani samo uz razloge koji se najčešće navode, rat te političku i ekonomsku nestabilnost u protekla dva i pol desetljeća. Problemi su strukturne prirode i rezultat su sustavne nebrige svih dosadašnjih vlasti i režima za iseljeništvo i za život građana u zemlji u cjelini. Primjerice migracijska politika i strategija u $\mathrm{BiH}$ nije nikada postojala, a ne postoji ni danas, unatoč brojnim institucijama kojima bi to trebalo biti u opisu posla. Danas je nema ni Hrvatska, a posljednja se doimala kao da je prepisana od neke useljeničke zemlje jer se uopće nije bavila iseljavanjem stanovništva (Božić, 2014).

Ozbiljan strukturni problem u Hrvatskoj je, kao i u BiH, što su gradovi srednje veličine tijekom cijelog 20. stoljeća zamjetno zaostajali u populacijskoj dinamici u odnosu na glavni grad. Srednji gradovi trebali su gospodarskim i društvenim razvojem zadržati stanovništvo iz svoga širega gravitacijskog područja, no zbog nepostojeće modernizacije to nisu uspjeli (Akrap, 2014: 33). Zato se seosko stanovništvo selilo prema najvećim središtima zaobilazeći male i srednje gradove, a često i najveće urbane sredine u zemlji (Akrap, 2004: 675-699). Prema Akrapu, upravo je to bitno za razumijevanje sadašnjeg stanja i objašnjenje zašto se hrvatsko stanovništvo uvijek odlijevalo prema inozemstvu. Hrvatska se razvijala centralizirano i monocentrično, pa su loši ekonomski parametri dijelom i izravna posljedica nejednakoga prostornog razvoja hrvatskog teritorija kao cjeline (Akrap, 2004: 675-699). Većina manjih mjesta naprosto je životarila gotovo bez ikakva ekonomskog i kulturnog sadržaja, pa ne čudi da su mladi iskoristili prvu priliku za »bijeg« iz zemlje.

Iako Njemačka nema neku strategiju koja bi ciljala na to da se veliki dio prostora Hrvatske i BiH isprazni, čini se da se upravo to događa. Prema studiji njemačke Zaklade Bertelsmann Stiftung (2015), broj radno sposobnih ljudi u Njemačkoj smanjit će se s oko današnjih 45 milijuna na manje od 29 milijuna do 2050. godine, što je pad za trećinu svih zaposlenih. Stoga je prema toj studiji Njemačka primorana svake godine uvesti minimalno 500.000 radnika kako bi održala tržište rada i funkcionalan mirovinski sustav na današnjoj razini. Useljavanje iz zemalja EU-a ubuduće će pak opadati zbog općega demografskog deficita u EU-u, pa će imigranti budućnosti stoga morati biti useljavani iz regija s velikim natalitetom - od Indije i Pakistana do Afrike - dakle iz zemalja s velikom kulturološkom razlikom i slabim obrazovnim sustavom. Stoga je jasno da će Njemačkoj u idućem razdoblju biti iznimno bitno uvesti što veći broj radnika iz zemalja EU-a i šire Europe. Upravo zbog toga i smatramo da će se u sljedećem razdoblju dogoditi izni- 
mno »usisavanje« radne snage iz područja Hrvatske, ali i cijele jugoistočne Europe. Smatramo da je vrlo izgledan nastavak iseljavanja mlade radne snage svih stupnjeva obrazovanja i različitih profesija iz Hrvatske.

Istraživanja navode kako je ukupna radna snaga u jugoistočnoj Europi bez intenzivnog iseljavanja od 1990. do 2016. mogla biti veća od 10 do 20\% od današnje (Atoyan i sur., 2016). Danas imamo čitav niz naselja čijih je članova više u Njemačkoj nego u matičnoj zemlji (primjerice hrvatska sela u općinama Orašju i Šamcu). Nijemci svakako dobro znaju da su Hrvati idealni radnici za potrebe njemačkoga gospodarstava jer su svojom obrazovnom razinom i načinom života već i prije dolaska u Njemačku prilagođeni potrebama njemačkog društva i tržišta rada. Integracija Hrvata u Njemačku košta nekoliko puta manje od useljenika iz arapskih zemalja i zbog toga su uvijek dobrodošli. Dokaze za to vidimo u njemačkim medijima, koji vrlo često pišu o izvrsnoj integriranosti Hrvata u Njemačkoj (Ex-Jugoslawen in Deutschland..., 2009).

\section{REZULTATI ISTRAŽIVANJA}

\subsection{Sociodemografski profil ispitanika}

Danas su visokoobrazovani, zaposlene osobe i osobe $u$ braku znatno skloniji migriranju, što u prijašnjim migracijama nije bio slučaj. Tzv. subjektivni motivi također nisu zanemarivi jer veliki broj iseljenika očekuje subjektivne dobiti od seljenja i motivira ih želja da dožive i upoznaju nešto novo ili da se usavrše u vlastitoj profesiji.

Prije iseljavanja bilo je 55,3\% zaposlenih ispitanika, 38,33\% bilo je nezaposlenih koji su aktivno tražili zaposlenje, a 9,16\% nezaposlenih koji nisu tražili zaposlenje. Zbog spomenutih ograničenja istraživanja i činjenice da su žene u pravilu spremnije odgovoriti na upitnik ne možemo zaključiti da se tijekom novijih iseljavanja iz zemlje iselilo više žena nego muškaraca (prema našim podacima, 53\% iseljenih su žene), no svakako možemo da su žene danas sklonije migriranju nego ikada prije. ${ }^{11}$ Valja naglasiti da su to žene u fertilnoj dobi, koje su nositeljice biološke obnove populacije. Najviše iseljenih čine osobe između 25 i 40 godina; na uzorku od 1200 ispitanika $58,33 \%$. To potvrđuju i podaci Državnog zavoda za statistiku Republike Hrvatske, prema kojima je najveći broj odseljenih u inozemstvo bio u dobi od 20 do 39 godina (46,7\%) (Migracija stanovništva Republike Hrvatske u 2016, 2017).

11 To dokazuje i studija njemačke Centrale za političko obrazovanje (Bundeszentrale für politische Bildung), prema kojoj na razini svjetskih migracija žene čine 49,6\% (Arbeitsmigration qualifizierter Frauen, 2009). 
Većina ispitanika su zaposlene osobe, koji najčešće imaju završenu srednju školu (60,7\%). Istraživanje koje je proveo Župarić-Iljić (2016) poklapa se s našim i pokazuje da je dvostruko porastao broj onih koji sa srednjom stručnom spremom odlaze iz zemlje u najproduktivnijoj radnoj i fertilnoj dobi, što ne čudi jer su oni i najzastupljeniji u općoj i u populaciji nezaposlenih (Župarić-Iljić, 2016: 6).

Udio je visokoobrazovanih u uzorku $37,8 \%$. Time je udio visokoobrazovanih osoba $\mathrm{u}$ iseljeničkom kontingentu u protekle tri godine za $12 \%$ veći nego u Hrvatskoj u dobnoj skupini $25-40 .{ }^{12}$ Danas je čak $31 \%$ svih useljenih migranata u Njemačku visokoobrazovano. ${ }^{13}$

Slika 2. U kojoj ste regiji živjeli neposredno prije preseljenja u Njemačku? $(\mathrm{N})$

Figure 2. In which Croatian region have you lived in before you moved to Germany? (N)

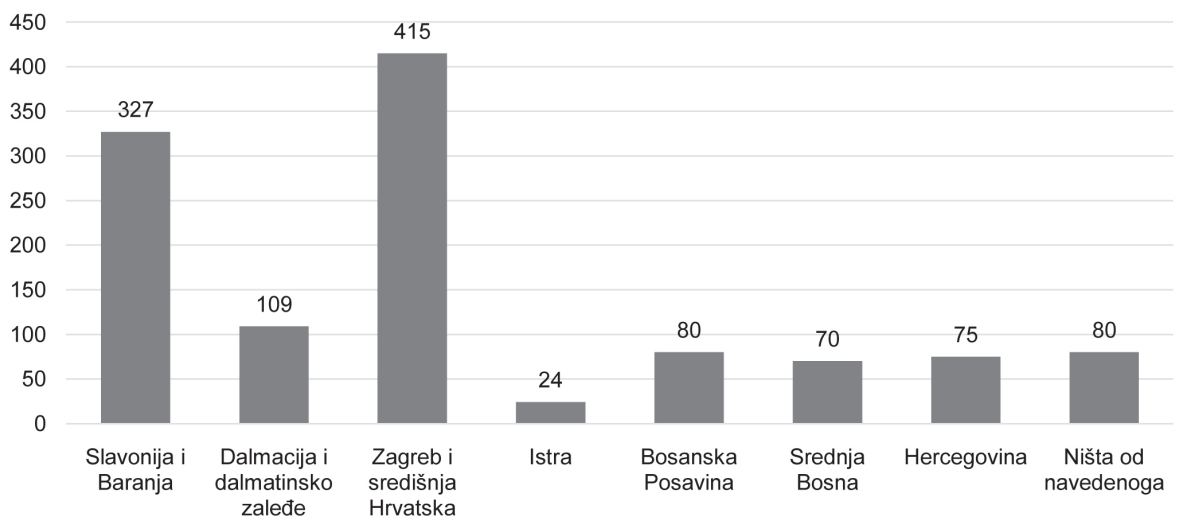

S obzirom na regionalnu pripadnost ispitanika najviše se osoba iselilo s područja Zagreba i okolice te Slavonije i Baranje (60\% svih ispitanika iz tih je regija) (slika 2).

Nisu dakle sva područja u Hrvatskoj izložena jednakim stopama iseljavanja. Istraživanje koje je proveo Drago Župarić-Iljić za Zakladu FriedrichEbert pokazuje da se relativno najviše ljudi iselilo iz Požeško-slavonske, Vukovarsko-srijemske, Sisačko-moslavačke, Ličko-senjske i Brodsko-posavske županije, što je prema regijama evidentno da je Slavonija, Baranja

12 Prosjek visokoobrazovanih osoba u Republici Hrvatskoj u dobnoj skupini $25-40$ jest 25\% (Popis stanovništva, kućanstava $i$ stanova 2011. godine, 2012).

13 Prema podacima dostupnim na internetskoj stranici Initiative Neue Soziale Marktwirtschaft (INSM), http://www.insm.de (30.01.2018.). 
i Srijem kao regija koja generirala omjerno najveći broj iseljenika, dok su četiri sjeverozapadne kontinentalne županije (Međimurska, Varaždinska, Krapinsko-zagorska i Koprivničko-križevačka) one gdje je taj omjer najmanji kao i u županijama koje ostvaruju najveću dobit od turizma (srednja i južna Dalmacija te Istra) (Župarić-Iljić, 2016: 6).

Naše istraživanje ne potvrđuje neoklasičnu ekonomsku pretpostavku uključenu u istraživanje Fassmanna i Hintermannove (1997) da će se visoki postotak potencijalnih migranata pronaći u regijama s najvećim gospodarskim problemima i među samim nezaposlenima, ali korespondiraju s njihovom pretpostavkom koju su dokazali Božić i Burić $(2005: 16,23)$ da najveći broj iseljenika čine osobe koje mogu kapitalizirati promjenu mjesta boravka i rada. Tako se potencijalni migranti pronalaze češće među mlađima koji pred sobom imaju još veliki dio radnog vijeka, među osobama koje nemaju jak osjećaj obveze prema obitelji, kao i među onima koji misle da imaju znanja koja se mogu kapitalizirati na tržištu rada, tj. među obrazovanijima te onima koji imaju migracijsko iskustvo, znaju strane jezike i onima čiji će troškovi integracije u novu sredinu biti manji te postojanju etničke zajednice u imigracijskoj zemlji.

Istraživanje pak ne potvrđuje Božićevu i Burićevu tezu (2005) da su nezaposlenost ili nemogućnost pronalaska odgovarajućeg posla u struci u $\mathrm{Hr}$ vatskoj glavni motivi iseljavanja. Osim toga je bitno obilježje ovog iseljavanja to da iseljavaju cijele obitelji, što je u prijašnjim migracijama u Njemačku bio rijedak slučaj.

Jedna od pretpostavki ovog rada bila je da je veliki dio iseljenih građana Hrvatske porijeklom iz $\mathrm{BiH}$, što je i potvrđeno rezultatom istraživanja koji pokazuje da je trećina ispitanika, odnosno hrvatskih državljana, porijeklom iz BiH. Vidimo da se oni po završetku rata često nisu mogli ili htjeli vratiti u svoj zavičaj te da su zbog toga najčešće izabrali Hrvatsku za daljnji život. Upravo su Hrvati iz BiH najčešće već imali iskustvo migracije u Njemačku tijekom Domovinskog rata, pa su se sada »najlakše« i odlučili za ponovnu migraciju.

U jedinom do sada objavljenom radu o novom iseljavanju Hrvata u Austriju Akrap, Strmota i Ivanda (2017: 547) ustanovili su da od ukupnoga broja useljenih Hrvata njih oko četrdeset posto ne dolazi iz Hrvatske te da je najvećim dijelom riječ o Hrvatima iz Bosne i Hercegovine.

Trošak integracije Hrvata iz BiH Hrvatsku nije koštao ništa. Budući da će zbog povećanog iseljavanja iz Hrvatske na tržištu rada doći do manjka radne snage, sasvim je izvjesno da će Hrvatskoj trebati strani radnici kako 
bi taj manjak nadomjestili. Integracija takvih radnika na tržište rada, ali i u ostale segmente društva puno je sporija ako su oni sociokulturno, jezično, pa i etnički različiti od domicilnog stanovništva, što nije bio slučaj s Hrvatima iz BiH. Tako zapravo sa svakim iseljenim Hrvatom ne samo da se gubi novac uložen u njegovo obrazovanje nego se i dobiva visok trošak integracije osobe koja će doći na njegovo mjesto.

Anđelko Akrap pokazuje da će se zbog iseljavanja iz BiH udio Srba i Hrvata u BiH i dalje smanjivati, dok će udio Bošnjaka rasti jer su u prosjeku najmlađi i manje se iseljavaju od Hrvata i Srba (Jurasić, 2016). Kod Bošnjaka je potpuno drugačija situacija i kod njih neće biti negativnih demografskih pokazatelja jer će se uz pozitivni prirast u BiH i useljavati muslimansko stanovništvo, na što hrvatska i srpska populacija ne mogu računati.

Budući da su danas u hrvatskoj populaciji u BiH gotovo svi demografski pokazatelji i trendovi negativni te potvrđuju ulazak u klasični demografski slom, sve će to imati jednako pogubne posljedice i na Hrvatsku jer je nestankom Hrvata u BiH presušio demografski bazen za revitalizaciju Hrvatske, u koju se desetljećima doseljavalo uglavnom hrvatsko stanovništvo iz $\mathrm{BiH}$ (Šterc, Milićević i Herceg, 2017: 517). Na djelu je vrlo vjerojatno povijesni odlazak Hrvata iz BiH nakon kojeg povratka više nema, a koji je dobrim dijelom uvjetovan neriješenom političkom situacijom u zemlji. 


\subsection{Razlozi iseljavanja}

Za većinu ispitanika odgovornost za sadašnju situaciju i masovno iseljavanje mladih iz zemlje snose nesposobni političari, neučinkovito pravosuđe i ratni profiteri (slika 3).

Slika 3. Razlozi iseljavanja (broj ispitanika koji izražavaju slaganje)

Figure 3. Reasons for emigration (number of respondents who agree)

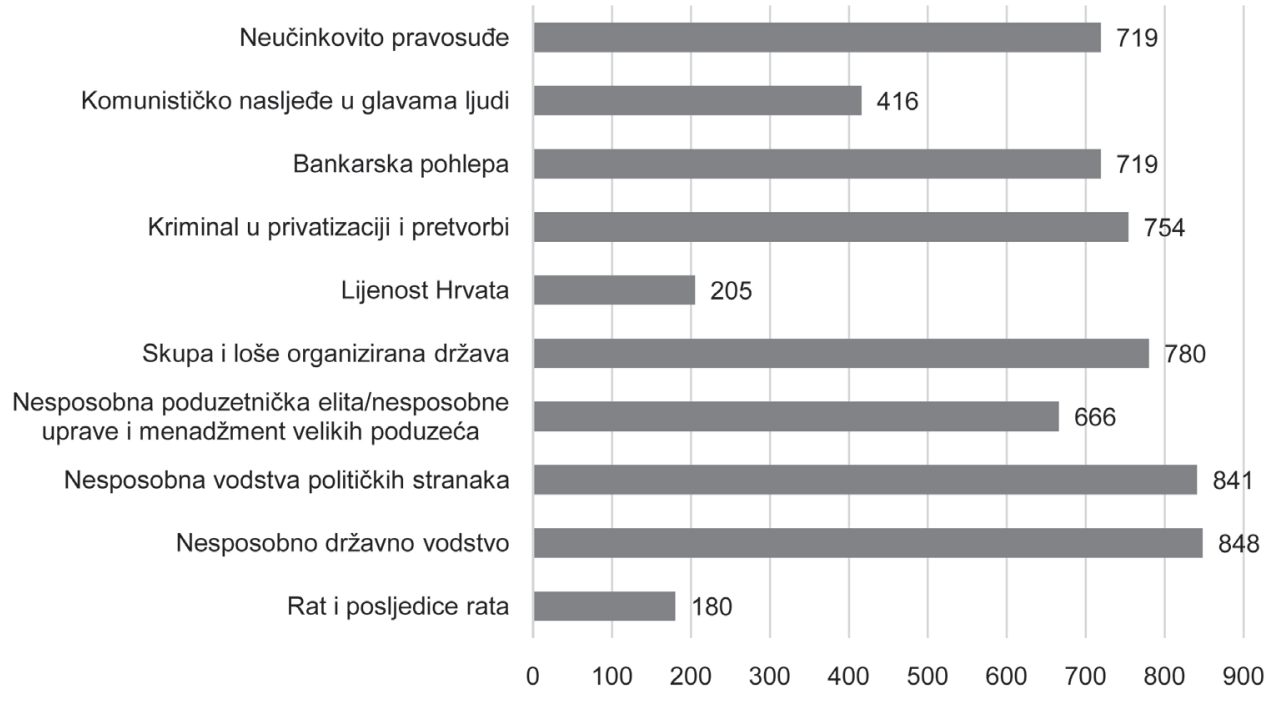

Iz grafičkog prikaza na slici 3 vidi se da ispitanici kao najvažnije razloge iseljavanja ističu nesposobne poduzetničke elite, vodstva političkih stranaka te kriminal u privatizaciji i pretvorbi. Najmanji je broj ispitanika kao razlog iseljavanja istaknuo rat i posljedice rata te lijenost Hrvata.

Kao glavni pokretač korupcije u Hrvatskoj često se ističu privatni interesi osoba na vlasti. Iz istraživanja o korupciji u Hrvatskoj vidimo da čak $62 \%$ ispitanika očekuje da će se naći u situaciji korupcijskog pritiska, odnosno da će se od njih tražiti mito u zamjenu za učinkovitije i brže rješavanje problema ili obavljanja posla (Izvješće o procjeni korupcije u 2016. godini, 2016). To upućuje i na vrlo nisku razinu povjerenja koje građani u Hrvatskoj imaju prema javnim institucijama i spremnosti države da se odlučno uhvati u koštac s koruptivnim praksama u svojim redovima. 
Slika 4. Motivi iseljavanja (N)

Figure 4. Motives of emigration (N)

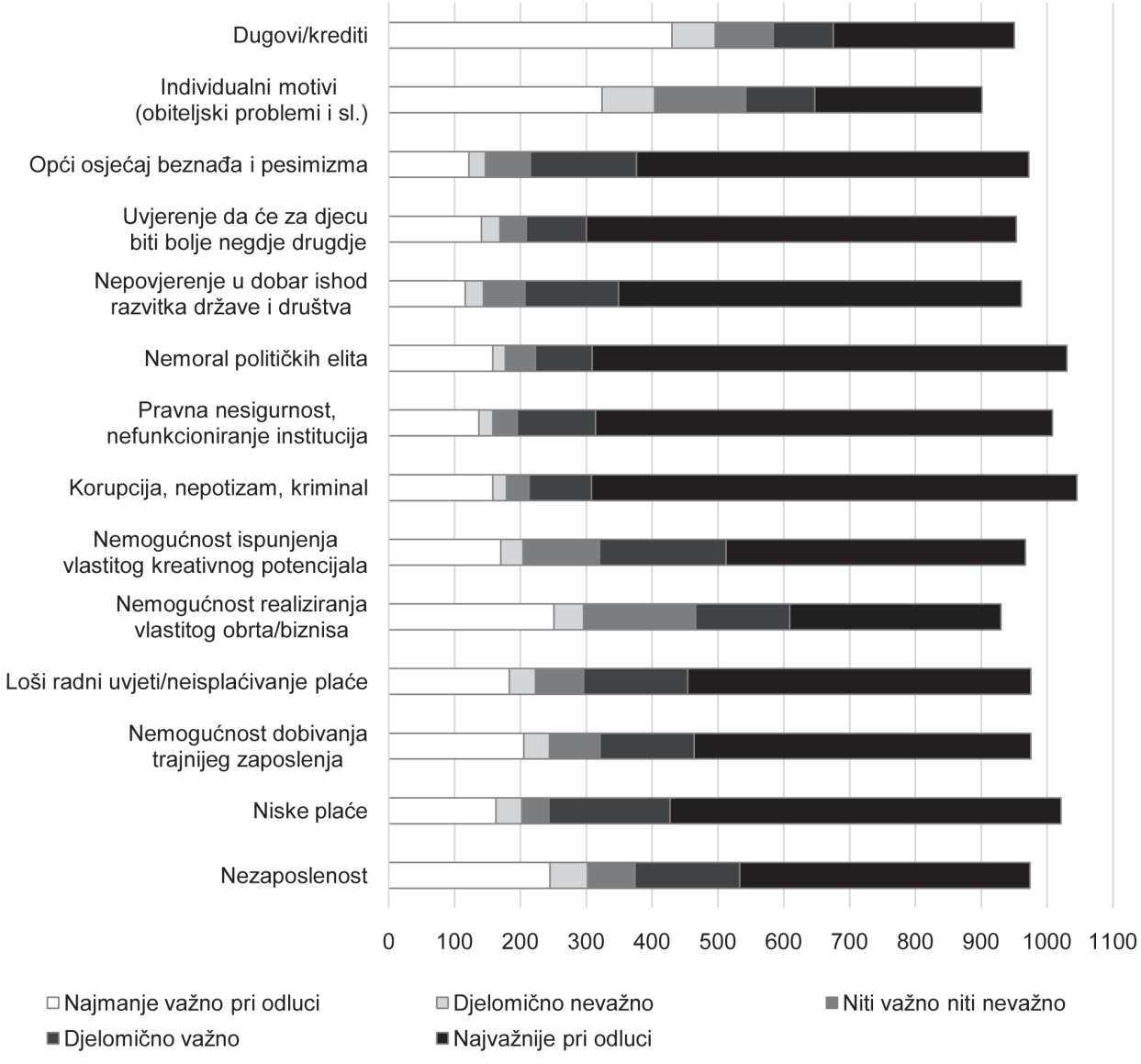

Ovdje se svakako ne umanjuju ekonomski motivi pri iseljavanju velikog broja hrvatskih državljana koji su procijenili da će u Njemačkoj imati veće mogućnosti za bolju zaradu ili bolje uvjete rada (slika 4). Dakako da život na »normalan način « (sintagma koju hrvatski iseljenici često upotrebljavaju) podrazumijeva ne samo uređenu državu, tj. javni i upravni aparat, nego i perspektivno gospodarstvo, pa time i priliku za posao i »normalan život«. Problemi slabe pravne države i slaboga gospodarstva povezani su, odnosno loša javna uprava i pravna država vode do socioekonomski nepovoljnih položaja većine građana te time i do nestabilnosti društvenog poretka i demokratskih deficita političkog sustava, besperspektivnosti i teško održivih standarda življenja. Naravno da je težnja za boljim životnim uvjetima i kva- 
litetom života te većom zaradom vječna tema svih ljudi koji žive u vremenu suvremenoga konzumerizma. Znamo da se ljudi ne mire s pukim preživljavanjem i zadovoljenjem primarnih potreba, već ih pokreću želja i nada da će odlaskom i zaposlenjem u bogatijoj zemlji ostvariti ideal o boljem i višem, na bilo kojoj razini (Peračković i Rihtar, 2016). Rezultati ovoga istraživanja pokazali su da su pri iseljavanju u Njemačku potisni čimbenici iz Hrvatske bili snažniji od privlačnih. Iako se privlačni čimbenici u ovome radu posebno ne analiziraju, $\mathrm{u}$ odgovorima ispitanika korupcija, pravna nesigurnost $\mathrm{i}$ nemoral političkih elita istaknutiji su od težnje za boljom zaradom.

Slika 5. Vrijednosni sustav iseljenika u Njemačku (broj ispitanika koji izražavaju slaganje)

Figure 5. Values of emigrants to Germany (number of respondents who agree)

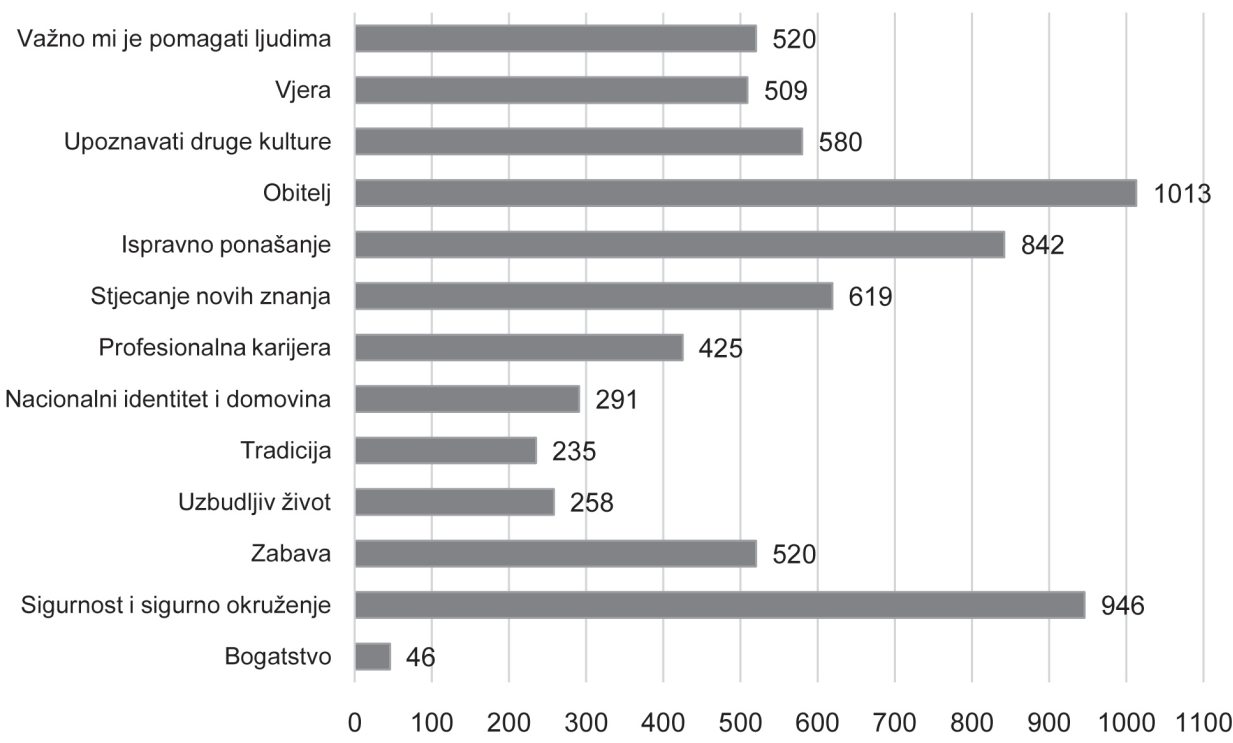

Nadalje, veliki udio ispitanika istaknuo je želju za sigurnošću, koju je većina pronašla u Njemačkoj kao percipiranoj državi blagostanja (slika 5). Ovaj dio rezultata pokazuje nam da je za najveći broj anketiranih iseljenika glavna vrijednost sigurnost, uz vrijednosti obitelji, koja je uvjerljivo najvažnija hrvatskim iseljenicima. Očito da je veliki broj ispitanika procijenio da ne može ostvariti dovoljnu razinu sigurnosti (političke, pravne i ekonomske) odnosno da ne želi (više) živjeti u neizvjesnosti. 
Vidimo da većina ispitanika iz Hrvatske ne odlazi radi materijalnog blagostanja, odnosno da bi se obogatili. Materijalno blagostanje za većinu iseljenika nije ključna životna vrijednost, štoviše, najmanje je važna. Peračković i Rihtar (2016) istražili su odnos materijalizma i namjera iseljavanja te postavili tezu da aktualnom iseljavanju pogoduje i sklonost materijalizmu kao latentni motiv, što je pak naše istraživanje opovrgnulo.

Nadalje vidimo da ljudi čeznu za poštenjem $i$ ispravnim ponašanjem $u$ društvu. Prema njihovoj percepciji Hrvatske, u zemlji nisu institucionalizirane vrijednosti poštenja $i$ ispravnog ponašanja.

Stjecanje novih znanja i profesionalna karijera mnogim su ispitanicima bitna tema (od liječnika do manualnih radnika). Iz dubinskih intervjua vidimo da iseljenim mladim stručnjacima smeta nemogućnost napredovanja u zemlji porijekla. Budući da nema ili je vrlo malo osobnih priznanja unutar sustava u kojima rade, mnogi mladi stručnjaci ne napreduju te neki i zato odlučuju otići. Ni subjektivni motivi zanemarivi jer velika većina ispitanika očekuje i »subjektivne dobiti« od seljenja te želi doživjeti i upoznati nešto novo. Veliki broj iseljenika navodi da su u inozemstvu bolje obrazovne mogućnosti za njih ili njihovu djecu. Hrvatski migranti općenito imaju visoke obrazovne težnje kada je riječ o njihovoj djeci (Božić i Burić, 2005) jer uviđaju važnost obrazovanja za poboljšanje socioekonomskog statusa obitelji.

Opciju nemogućnosti realizacije vlastitog poduzeća u domovini (slika 4) izabrao je također veliki broj ispitanika. Riječ je o malim i srednjim poduzetnicima, koji bi zapravo trebali biti nositelji gospodarskog razvoja društva. Naime sve analize Zaklade Konrad-Adenauer pokazuju da je hrvatsko gospodarstvo nerazvijeno upravo zbog manjka malih i srednjih poduzetnika, a da je njemačko upravo zbog njih uspješno. ${ }^{14}$

Nezanemariv je i broj ispitanika koji su odlučili napustiti zemlju zbog nemogućnosti vraćanja kredita, odnosno blokiranih građana. U Hrvatskoj je krajem 2017. godine 328,9 tisuća građana imalo blokirane račune. Kada se tom broju blokiranih pridodaju njihove obitelji, dobije se broj od gotovo milijun građana ili četvrtine hrvatskog stanovništva izravno pogođenog problemima prezaduženosti i svim teškim posljedicama koje iz toga proizlaze (»Živjeti u Hrvatskoj i biti blokiran« ..., 2017).

Cijeli spektar motiva i poticaja za iseljavanje svakako nam nije bilo moguće istražiti, ali se nadamo da smo ovim istraživanjem dali mali doprinos ovoj temi.

14 Zaklada Konrad Adenauer, http://www.kas.de/kroatien/hr/publications/. 


\subsection{Zadovoljstvo životom u Njemačkoj}

Posebno je zanimljivo pogledati rezultate ocjene zadovoljstva svojim »novim životom « u Njemačkoj, prema kojima je čak 79\% ispitanika zadovoljno, a svega 3\% nezadovoljno, što potvrđuje i rezultat da $65,2 \%$ iseljenika nije požalilo što se odselilo u Njemačku, a $80 \%$ tvrdi da su im se ispunila očekivanja u vezi s poboljšanjem životnih okolnosti u Njemačkoj. Nadalje, 73\% hrvatskih građana zadovoljno je svojom plaćom u Njemačkoj, dok samo 5\% nije zadovoljno. Čak je i smještajem, koje se po iseljeničkim forumima ${ }^{15}$ najčešće spominje kao najspornija stavka života u Njemačkoj, velika većina zadovoljna - 69\%, dok je svega 7,2\% njime nezadovoljno.

Gotovo polovina ispitanika, $47 \%$, imala je $\mathrm{u}$ domovini primanja do petsto eura neto te prema tome bila ispodprosječno plaćena. Stoga ne iznenađuje podatak da je većina iseljenih Hrvata u Njemačkoj, njih 73,1\%, zadovoljna svojom plaćom, uzevši u obzir da je realna prosječna plaća u Njemačkoj 1542 eura (STATISTA, 2017a). Prema navodima Saveznog ureda za statisti$\mathrm{ku}$, prosječna neto plaća u Njemačkoj bila je 2015. godine 1850 eura (STATISTA, 2017a), a u Hrvatskoj 6025 kuna, odnosno 802 eura (HINA, 2017). Usporedbom dolazimo do toga da su plaće u Njemačkoj veće dva do dva i pol puta nego u Hrvatskoj.

U Njemačkoj je na dan 2. studenoga 2017. bilo 39 milijuna zaposlenih, od kojih 2,7 milijuna radi dodatni posao, što čini 6,92\% (STATISTA, 2017b). Hrvata je pak 20,1\% koji rade dodatni posao, dakle znatno više od prosjeka u Njemačkoj.

\subsection{Emocionalni doživljaj života u Njemačkoj}

Set pitanja koja provjeravaju emocionalni doživljaj života u Njemačkoj pokazuje da se većina osjeća "generalno bolje« nego u matičnoj zemlji, da nostalgija nije prevladavajuća emocija (kao što se inače u hrvatskom diskursu o migrantima često tvrdi) te da znatna većina osjeća kako u Njemačkoj više dobiva u subjektivnom i objektivnom smislu nego što gubi u matičnoj državi (slika 6).

Rezultati pokazuju da se hipoteza da se hrvatski iseljenici u Njemačkoj osjećaju otuđeno te da imaju izrazit osjećaj da su stranci može odbaciti.

Zanimljivo je i uočiti da veliki postotak ispitanika počinje doživljavati Njemačku svojom domovinom.

Vidi primjerice grupu na Facebooku »Idemo u svijet - Njemačka«. 
Slika 6. U Njemačkoj se osjećam... (N)

Figure 6. In Germany I feel... (N)

Osjećam se generalno bolje nego u domovini

Osjećam se osamljeno i otuđeno

Radim napornije nego u domovini

Osjećam nostalgiju

U Njemačkoj imam ispunjene sve uvjete za dobar život

Osjećam se lošije nego u domovini

Imam osjećaj da više dobivam u stranoj zemlji, nego što gubim u domovini

U Njemačkoj se osjećam kao stranac

Njemačku doživljavam kao svoju novu domovinu

Osjećam kao da nigdje više ne pripadam
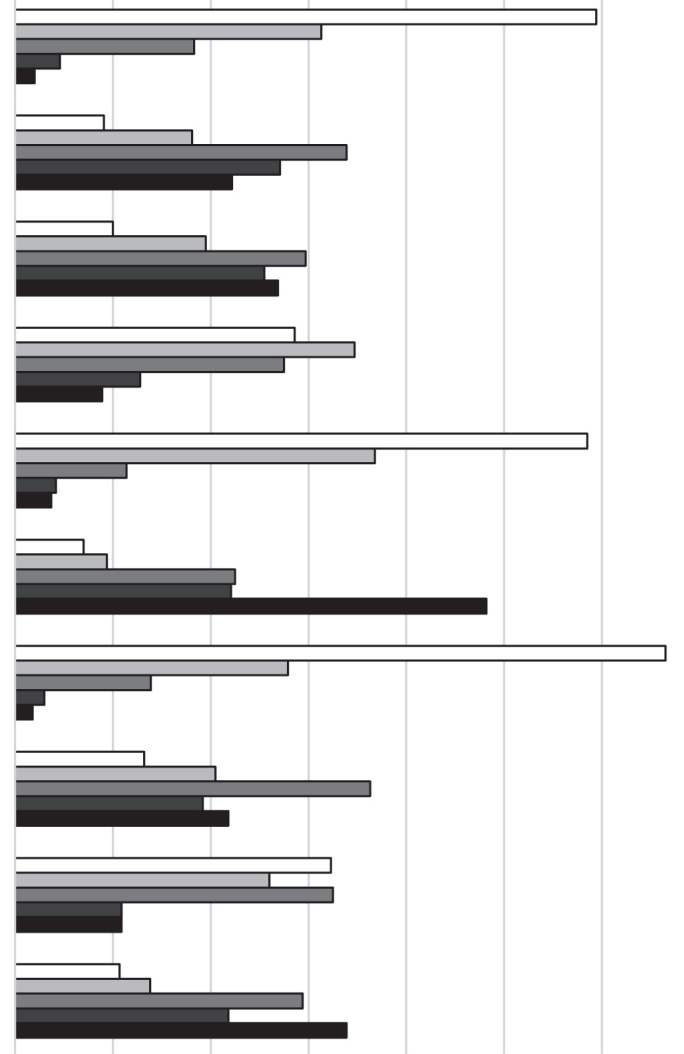

$\begin{array}{llllllll}0 & 100 & 200 & 300 & 400 & 500 & 600 & 700\end{array}$

$\square U$ potpunosti se slažem

$\square$ Niti se slažem niti ne slažem

-U potpunosti se ne slažem

\section{口Slažem se}

- Ne slažem se

No istina je i da nisu svi ispitanici koje smo ovim istraživanjem obuhvatili zadovoljni svojim životom u Njemačkoj. Na temelju provedenih intervjua zaključujemo da se za dio njih migracija pokazala životnim razočaranjem. $S$ druge strane, mnogi svjedoče i da se srame vratiti u domovinu zbog osjećaja neuspjeha, sramote i straha od ruganja (Soldo, 2017). Posebni je problem za mnoge iseljenike okolnost što zbog rada nemaju vremena upisati školu njemačkog jezika (jer mnogima posao to ne dozvoljava), zbog čega 
ne mogu tražiti bolje plaćene poslove, što generira daljnje nezadovoljstvo (Soldo, 2017).

Iako brojni iseljenici u Njemačkoj objektivno žive znatno teže nego što bi ikada živjeli u domovini, imaju nadu da će im jednom biti bolje, dok su tu nadu kad je riječ o Hrvatskoj izgubili (Bogdanić, 2017). Mnogi su u Njemačkoj spremni na puno više odricanja, trpljenja i patnje nego u domovini, naprosto zato što vjeruju da će im se taj trud isplatiti.

\section{ZAKLJUČAK}

Ovo je istraživanje eksplorativnoga karaktera i nastoji rasvijetliti pozadinu novijih iseljavanja iz Hrvatske. Rad je prvo empirijsko istraživanje uzroka i motiva novijih iseljavanja Hrvata u Saveznu Republiku Njemačku i pokazuje kako glavni motivi iseljavanja - prema percepciji samih iseljenika - nisu ekonomski. Analiza iseljeničkih stavova pokazala je da je glavni poticaj odlasku iz zemlje predodžba da u Hrvatskoj nisu institucionalizirane vrijednosti radne etike i uopće poštenja. Percepcija je iseljenika da se hrvatsko društvo moralno slomilo.

Istraživanje upućuje na jasnu vezu između političke etike, slabih institucija i iseljavanja. Većina naših ispitanika slaže se da Hrvatska nije društvo koje svojim građanima osigurava dostojan život i perspektivu, odnosno pravnu sigurnost, ekonomski prosperitet i mogućnost profesionalnog razvoja.

Postojanje razgranatih hrvatskih migrantskih mreža iz prošlosti u Njemačkoj olakšava i potiče migraciju. Vidimo da je broj iseljenih u Njemačku znatno veći od onoga koji je zabilježila službena statistika, a osnovni su trendovi iseljavanja sljedeći: iseljavaju se mlade osobe između dvadeset i četrdeset godina (58,33\%), koje su pretežito bile zaposlene te u pravilu s cijelim obiteljima. Iseljeni Hrvati svojim su »novim životom « u Njemačkoj u pravilu vrlo zadovoljni i nisu požalili što su se odselili u Njemačku. Sukladno tome, rijetki razmišljaju o povratku.

Hrvatskim društvom danas neupitno vlada jedna vrsta moralne panike i kolektivne psihoze, koje su posljedica iseljavanja oko pet posto ukupnog stanovništva, i to u samo protekle četiri godine. Posebni problem u fenomenu iseljavanja čine mediji, koji cijelu temu prikazuju pristrano i kao da navijaju za odlazak ljudi iz zemlje. ${ }^{16}$ Tako se u društvu stvara slika da su oni koji su otišli uspjeli, a da su oni koji ostaju gubitnici.

16 Vidi pojam/kategoriju »iseljavanje«, primjerice u: Indeks.hr, Večernji list i Jutarnji list. 
Pokazali smo da su potisni čimbenici iz Hrvatske izraženi u kontekstu iseljavanja u Njemačku, što se posebice odnosi na korupciju, pravnu nesigurnost i nemoral političkih elita. Većina tvrdi da je izgubila povjerenje u domovinu i vjeru da će hrvatsko društvo u nekom kratkoročnom do srednjoročnom razdoblju uspjeti postati zdravo društvo.

Uz te postoje i strukturni razlozi iseljavanja koji proizlaze iz modela centralizacije gospodarstva i naslijeđenog neravnomjernog razmještaja stanovništva postavljenog za vrijeme SFRJ kao i nemara i nebrige svih dosadašnjih hrvatskih vlasti da se taj model ispravi. Izostalo je jačanje gradova srednje veličine nauštrb centralizacije zemlje, što je dovelo do toga da su veliki dijelovi zemlje ostali bez ikakva gospodarskoga i kulturnog sadržaja. Prepušteni sami sebi, najčešće nisu mogli ostvariti dovoljnu atraktivnost za zadržavanje mladih ljudi i obitelji.

Usto, postojanje razgranatih hrvatskih migrantskih mreža iz prošlosti u Njemačkoj olakšava i potiče migraciju. Može se dakle zaključiti da je veliki dio današnjega masovnog iseljavanja bio ugrađen $u$ hrvatsko društvo još u prošlosti. Iseljavanje je svakako potaknulo i lobiranje hrvatskih vlasti da Njemačka ukine restrikcije za hrvatske radnike 1. srpnja 2015., otkada pratimo nagli porast iseljavanja.

Za većinu ispitanika odgovornost za sadašnju situaciju i masovno iseljavanje mladih iz zemlje snose nesposobni političari, neučinkovito pravosuđe i ratni profiteri. Nemoral političkih elita, pravna nesigurnost, nepotizam i korupcija pri vrhu su motiva koji su pridonijeli iseljavanju. Istraživanje je potvrdilo da su politička neizvjesnost i nestabilnost mnogima bile poticaj za odlazak. Većina traži sigurnost i uređen sustav. Svakako ne umanjujemo ni ekonomske motive iseljavanja, ali ih ne smatramo presudnima. Na temelju rezultata istraživanja vidjeli smo da mladi Hrvati ne odlaze radi novca, odnosno da bi se obogatili. Bogatstvo nikome od njih nije ključna vrijednost. Oni su u Njemačkoj spremni na puno više odricanja, trpljenja i patnje nego u domovini, naprosto zato što vjeruju da će im se taj trud u Njemačkoj isplatiti, dok su u domovinu izgubili povjerenje.

Većina iseljenih ispitanika zaposlene su osobe, najčešće imaju završenu srednju školu (60,7\%), dok je udio visokoobrazovanih $37,8 \%$. Time je udio visokoobrazovanih osoba $u$ iseljeničkom kontingentu $u$ protekle tri godine za $12 \%$ veći nego u domovini u dobnoj skupini $25-40$. S obzirom na regionalnu pripadnost ispitanika, najveću sklonost migriranju iskazuju ispitanici iz područja Zagreba i okolice te Slavonije i Baranje (60\% svih iseljenih iz tih je regija). 
Posebno je zanimljivo pogledati rezultate ocjene zadovoljstva svojim »novim životom « u Njemačkoj, prema kojima je čak 79\% ispitanika zadovoljno, a svega tri posto nezadovoljno, što potvrđuje i kontrolno pitanje, prema kojemu $65,2 \%$ iseljenika nije požalilo što se odselilo u Njemačku, a $80 \%$ tvrdi da su im se ispunila očekivanja u vezi s realizacijom u Njemačkoj.

Sudeći prema dobivenim podacima, trećina ispitanih iseljenih Hrvata u Njemačku, odnosno državljana Hrvatske, porijeklom je iz BiH. Hrvati iz $\mathrm{BiH}$, koji su tradicionalno nadomještali manjak stanovništva u Hrvatskoj, danas Hrvatsku zaobilaze. A sa svakim iseljenim Hrvatom zapravo ne samo da se gubi novac uložen u njegovo obrazovanje, nego se i dobiva visoki trošak integracije osobe koja će doći na njegovo mjesto.

Emocionalni doživljaj života u Njemačkoj pokazuje da se većina osjeća "generalno bolje« nego u domovini, da nostalgija nije prevladavajuća emocija (kao što se inače u hrvatskom diskursu o migrantima često tvrdi) te da znatna većina osjeća kako u Njemačkoj više dobiva u subjektivnom i objektivnom smislu nego što gubi u domovini. Istraživanje pokazuje i da teza kako hrvatski iseljenici rade napornije u Njemačkoj nego u domovini ne stoji, kao ni široko rasprostranjena predrasuda da se hrvatski iseljenici u Njemačkoj osjećaju otuđeno te da imaju izrazit osjećaj da su stranci. Moguće je da je ovdje na djelu fenomen socijalno poželjnih odgovora, no ovi pokazatelji svakako nam daju prve uvide u situaciju.

Zanimljivo je vidjeti i da veliki postotak novoiseljenih Hrvata počinje doživljavati Njemačku svojom domovinom.

Kako god pristupili fenomenu iseljavanja Hrvata, jedno je sigurno: mlade u zemlji svakako se više ne može zadržati praznim obećanjima i govorima lišenih svakog sadržaja. Vremena su se promijenila i mladi danas konačno imaju alternativu, pa ne moraju biti zatočenici loših politika i lošeg upravljanja zemljom i društvom. Svakako bi bilo licemjerno upirati prstom samo u političare i tražiti isključivu krivnju za iseljavanje mladih samo kod njih. Poznato je da vlast izbjegava ključna pitanja, no i ostali društveni akteri moraju biti više angažirani. Tako smo zapravo za nastalu situaciju krivi pomalo svi mi koji djelujemo u javnom životu zemlje.

Cijeli spektar motiva i poticaja za iseljavanje svakako nam nije bilo moguće istražiti, ali se nadamo da smo ovim istraživanjem potaknuli daljnje bavljenje ovom temom.

Na samom kraju, u tablici 8, donosimo neke od brojnih ideja, komentara i razmišljanja koje je čak 947 ispitanika iznijelo na posljednje, otvoreno pitanje $\mathrm{u}$ anketi: »Na kraju, molimo Vas da u predviđenom prostoru (ako 
želite) iznesete svoje ideje i razmišljanja što biste osobno poručili Vladi RH i Saboru RH po pitanju teme migracija Hrvata.«

Tablica 8. Odabrane ideje, komentari i razmišljanja ispitanika

Table 8. Selected ideas, comments and thoughts of respondents

\section{Neki primjeri izjava}

»...zar mi je tata poginuo da bi služio Nijemcu, ali eto hvala bogu bolje i

Nijemcu služiti i biti sit nego Hrvatu i biti gladan...«

»Dok se još uvijek prepucavaju tko je gdje bio 1941., a tko gdje 1991., mi 2017. živimo u nekoj drugoj zemlji.«

»Tek je počelo... a posljedice će biti gigantskih razmjera. Nadam se da to vidite. Samo rad i poštenje se isplate... možda je to duži put ali je pravi. (...) Kamo sreće da smo ovih 20ak godina radili sa srcem i punim zalaganjem za boljitak cijele države - bili bi daleko.«

»Žalosno što mladi školovani ljudi odlaze sami u tuđinu, gdje prolijevaju more suza učeći sve ispočetka i nikad neće ovdje moći napredovati kao što bi to mogli u svojoj zemlji na svom jeziku.«

»Žalosno je što svjedočimo sahranjivanju jedne tako prosperitetne i lijepe male zemlje koja je nastala na rijeci krvi, suza i bola.«

»Hrvatski političari u $\mathrm{BiH}(. .$.$) su protjerali više Hrvata svojim kriminalnim$ radnjama, spletkama te namještanjima natječaja za podobne, nego Osmansko carstvo u svoje vrijeme. Na rubu smo nestanka. U istom smjeru ide i RH. Jednog dana će se vaša imena spominjati u udžbenicima povijesti ali sigurno ne u pozitivnom kontekstu.«

»Po tom pitanju poručit ću im da mi je to bila najteža odluka u životu da s obitelji i dvoje male djece odem u nepoznato. Toliko teška da sam se razbolila... nikad im to neću oprostiti i zaboraviti. Nadam se da se nikad neću vratiti. U Njemačkoj se trenutno oporavljam i pomažu mi. Danke Deutschland.«

»Kad vidim što rade ponekad se stidim što sam Hrvat! Nema gorih političara... Tisuću godina nismo imali svoju državu... bolje bi bilo da ju nismo imali ni narednih tisuću... nema većih neprijatelja Hrvatima od samih Hrvata...« 


\section{LITERATURA}

Akrap, A. (1998). Saldo migracija Republike Hrvatske i županija 1971.-1981. i 1981.1991. za ukupno stanovništvo i stanovništvo u zemlji, u: I. Lajić (ur.). Migracije u Hrvatskoj - regionalni pristup. Zagreb: IMIN, 11-68.

Akrap, A. (2004). Zapošljavanje u inozemstvu i prirodna depopulacija seoskih naselja, Društvena istraživanja, 13 (4-5): 675-699.

Akrap, A. (2014). Promjene broja i prostornog razmještaja stanovništva Hrvatske i županija, 1961.-2011., u: V. Puljiz, J. Tica i D. Vidović (ur.). Migracije i razvoj Hrvatske. Podloga za hrvatsku migracijsku strategiju. Zagreb: Hrvatska gospodarska komora, 2574.

Akrap A. i Strmota, M. (2015). Veliki iseljenički valovi iz Hrvatske od kraja 19. do kraja 20. stoljeća, u: M. Sopta, F. Maletić i J. Bebić (ur.). Hrvatska izvan domovine I. Zagreb: Golden marketing - Tehnička knjiga, 71-79.

Akrap, A., Strmota, M., i Ivanda, K. (2017). Iseljavanje iz Hrvatske od početka 21. stoljeća: uzroci i posljedice, u: M. Sopta i dr. (ur.). Hrvatska izvan domovine II . Zagreb: Centar za istraživanje hrvatskoga iseljeništva - Centar za kulturu i informiranje Maksimir, 543-551.

Arbeitsmarkt braucht künftig mehr Einwanderung aus Nicht-EU-Staaten, Pressemeldung, Bertelsmann Stiftung, 27.03.2015., https://www.bertelsmannstiftung.de/de/presse/pressemitteilungen/pressemitteilung/pid/arbeitsmarktbraucht-kuenftig-mehr-einwanderung-aus-nicht-eu-staaten/ (15. siječnja 2018.).

Arbeitsmigration qualifizierter Frauen, Bundeszentrale für politische Bildung, 2009, http://www.bpb.de/gesellschaft/migration/kurzdossiers/57289/migration-vonfrauen (10.11.2017.).

Atoyan, R., Christiansen, L., Dizioli, A., Ebeke, C., Ilahi, N., Ilyina, A., Mehrez, G., Qu, H., Raei, F., Rhee, A. i Zakharova, D. (2016). Emigration and Its Economic Impact on Eastern Europe. Washington, D.C.: IMF (Staff Discussion Notes, 16/7) https:// www.imf.org/external/pubs/ft/sdn/2016/sdn1607.pdf, doi: https://doi.org/10.5089/ 9781475576368.006

Bachner, M. (2018). Regierung öffnet neue Balkanroute, Kurirer.at, 17.01.2018., https://kurier.at/politik/inland/regierung-oeffnet-neue-balkanroute/307.089.346 (28.01.2018.).

Bogdanić, S. (2017). Novi iseljenici iz Hrvatske: Odlaze oni koji već imaju posao, Deutsche Welle, 18.12.2017., http://www.dw.com/hr/novi-iseljenici-iz-hrvatske-odlaze-onikoji-ve\%C4\%87-imaju-posao/a-41829200 (04.01.2018.).

Božić, S. i Burić, I. (2005). Migracijski potencijal Hrvatske - mikroanalitički aspekti, Migracijske i etničke teme, 21 (1-2): 9-33.

Božić, S. (2014). Hrvatska migracijska politika: Od skice prema strategiji, u: V. Puljiz, J. Tica i D. Vidović (ur.). Migracije i razvoj Hroatske. Podloga za hrvatsku migracijsku strategiju. Zagreb: Hrvatska gospodarska komora, 285-300.

Čipin, I. (2014.). Stručna podloga za izradu Strategije prostornog razvoja Republike Hrvatske: Demografski scenariji i migracije. Zagreb: Sveučilište u Zagrebu, Ekonomski fakultet, Katedra za demografiju.

Čizmić, I., Sopta, M. i Šakić, V. (2005). Iseljena Hrvatska. Golden marketing - Tehnička knjiga: Zagreb. 
Doppelt so viele Kroaten beantragen deutschen Pass, Welt.de, 29.06.2015., https://www. welt.de/politik/deutschland/article143291757/Doppelt-so-viele-Kroaten-beantragendeutschen-Pass.html (27.01.2018.).

Ex-Jugoslawen in Deutschland. Die meisten fallen als Ausländer gar nicht mehr auf, T-Online.de, 12.08.2009., http://www.t-online.de/nachrichten/deutschland/ gesellschaft/id_19670878/ex-jugoslawen-in-deutschland-die-meisten-fallen-alsauslaender-gar-nicht-mehr-auf-.html (21.10.2017.).

Fassmann, H. i Hintermann, C. (1997). Migrationspotential Ostmitteleuropa. Struktur und Motivation potentieller Migranten aus Polen, der Slowakei, Tschechien und Ungarn. Wien: Verlag der Österreichischen Akademie der Wissenschaften.

Grizelj, M. i Akrap, A. (2011). Projekcije stanovništva Republike Hrvatske od 2010. do 2061. Zagreb: Državni zavod za statistiku.

HINA (2017). Prosječna plaća u Hrvatskoj 6.025 kuna: Saznajte u kojem sektoru se najviše zarađuje, a u kojem je prosječna plaća samo 3.653 kuna, Jutarnji list, 04.08.2017., http://www.jutarnji.hr/biznis/karijere/prosjecna-placa-u-hrvatskoj-6025-kunasaznajte-u-kojem-sektoru-se-najvise-zaraduje-a-u-kojem-je-prosjecna-placa-samo3653-kuna/6433489/ (02.11.2017.).

Izvješće o procjeni korupcije u 2016. godini (2016). Zagreb: Center for the Study of Democracy - Partnerstvo za društveni razvoj, http://integrityobservers.eu/UserDocsImages/ izvjesce_o_procjeni_korupcije_2016_HR.pdf (16.01.2018.).

Jurasić, D. (2016). Odraz demografske slike BiH na Hrvatsku: Evo koliko će Hrvata ostati u BiH za 10 godina!, Večernji list, 08.07.2016., https://www.vecernji.hr/vijesti/ od-410000-hrvata-u-bih-za-10-godina-ostat-ce-ih-300000-1097807 (26.10.2017.).

Lee, E. S. (1966). A Theory of Migration, Demography, 3 (1): 45-57, doi: https://doi. org/10.2307/2060063

M. D. (2017). Njemačko državljanstvo uzima sve više Hrvata - evo i zašto, Fenix magazin, 07.11.2017., https://fenix-magazin.de/njemacko-drzavljanstvo-godisnje-uzima-svevise-hrvata-evo-i-koliko-00/ (12.11.2017.).

Mesić, M. (2014.) Međunarodne migracije: teorijski pristupi, u: V. Puljiz, J. Tica i D. Vidović (ur.). Migracije i razvoj Hrvatske. Podloga za hrvatsku migracijsku strategiju. Zagreb: Hrvatska gospodarska komora, 157-174.

Ministarstvo sigurnosti Bosne i Hercegovine (2016.) Strategija u oblasti migracija i azila $i$ akcijski plan za razdoblje 2012-2015., Sarajevo, http://msb.gov.ba/PDF/Strategija_ HRV_2016.pdf (29.12.2017.).

Ministarstvo financija Republike Hrvatske (2016). Državni proračun 2017. godina, http:// www.mfin.hr/hr/drzavni-proracun-2017-godina (20.01.2018.).

Polegubić, A. (2015). Hrvatsko dušobrižništvo u Njemačkoj: stanje i perspektiva, u: M. Sopta, F. Maletić i J. Bebić (ur.). Hrvatska izvan domovine I. Zagreb: Golden marketing - Tehnička knjiga, 55-65.

Peračković, K. i Rihtar, S. (2016). Materijalizam kao društvena vrijednost i poticaj namjerama iseljavanja iz Hrvatske, Migracijske i etničke teme, 32 (3): 295-317, doi: https://doi.org/10.11567/met.32.3.1

Rogić, I. i Čizmić, I. (2011). Modernizacija u Hrvatskoj i hrvatska odselidba. Zagreb: Institut društvenih znanosti Ivo Pilar.

Schellinger, A. (ur.) (2015). Brain Drain - Brain Gain: European Labour Markets in Times of Crisis. Bonn: Friedrich-Ebert-Stiftung, http://library.fes.de/pdf-files/id/ipa/12032.pdf (28.01.2018.). 
Soldo, V. (2017). Ne uspiju svi u Njemačkoj, Deutsche Welle, 07.11.2017., http://m.dw.com/ hr/ne-uspiju-svi-u-njema\%C4\%8Dkoj/a-41260729 (16.11.2017.).

Stanković, V. (1982). Crkva i hrvatsko iseljeništvo. Zagreb: Kršćanska sadašnjost.

Šakić, V., Ivanda-Serdar, K., Jurčević, J., Mišetić, A., Mlačić, B. i Pokos, N. (1997). Sociodemografski, migracijski, povratničko-motivacijski i psihosocijalni status hrvatskih povratnika iz iseljeništva (elaborat). Zagreb: Institut društvenih znanosti Ivo Pilar.

Šterc, S. (2017). Demografski razvoj Hrvatske kao temelj planiranja mirovinskog sustava, http://mirovinskifondovi.hr/wp-content/uploads/2017/03/DEMOGRAFSKAKONFERENCIJA-stjepan-sterc-studija.pdf (29.09.2017.).

Šterc, S., Milićević, M. i Herceg, N. (2017). Hrvati u BiH: demografska stvarnost, u: Hrvati Bosne i Hercegovine: nositelji europskih vrijednosti, 564-575.

Vedriš, M., Letica B. i Letica, S. (2012). Gospodarsko stanje hrvatske nacije 2011. - 2012. Analiza rezultata jednog empirijskog istraživanja, Délkelet-Európa-South-East Europe International Relations Quarterly, 3 (4): 1-23.

Volle Öffnung des Arbeitsmarktes für Kroatien ab 1. Juli 2015, Pressemitteilungen, 17. Juni 2015, Bundesministerium für Arbeit und Soziales, http://www.bmas.de/ DE/Presse/Pressemitteilungen/2015/freizuegigkeit-volle-oeffnung-arbeitsmarktkroatien.html (27.09.2017.).

Wertheimer-Baletić, A. (1999). Stanovništvo i razvoj. Zagreb: Mate.

»Živjeti u Hrvatskoj i biti blokiran« - stručni skup održan na Pantovčaku, www. blokirani.hr, 19. lipnja, 2017, http://www.blokirani.hr/zivjeti-u-hrvatskoj-i-bitiblokiran-strucni-skup-odrzan-pantovcaku-19-06-17/ (24. veljače 2018.).

Župarić-Iljić, D. (2016). Iseljavanje iz Republike Hrvatske nakon ulaska u Europsku uniju. Zagreb: Friedrich-Ebert-Stiftung.

\section{IZVORI}

Bevölkerung und Erwerbstätigkeit: Ausländische Bevölkerung. Ergebnisse des Ausländerzentralregisters, 2014, Fachserie 1 Reihe 2, Statistisches Bundesamt (Destatis), Wiesbaden, 2015, https://www.destatis.de/DE/Publikationen/Thematisch/ Bevoelkerung/MigrationIntegration/AuslaendBevoelkerung2010200147004.pdf? blob=publicationFile

Bevölkerung und Erwerbstätigkeit: Ausländische Bevölkerung. Ergebnisse des Ausländerzentralregisters 2015, Fachserie 1 Reihe 2, Statistisches Bundesamt (Destatis), Wiesbaden, 2016, https://www.destatis.de/DE/Publikationen/Thematisch/ Bevoelkerung/MigrationIntegration/AuslaendBevoelkerung2010200157004.pdf? blob=publicationFile

Bevölkerung und Erwerbstätigkeit: Ausländische Bevölkerung. Ergebnisse des Ausländerzentralregisters, 2016, Fachserie 1 Reihe 2, Statistisches Bundesamt (Destatis), Wiesbaden, 2017, https://www.destatis.de/DE/Publikationen/Thematisch/ Bevoelkerung/MigrationIntegration/AuslaendBevoelkerung2010200167004.pdf? blob=publicationFile

Freizügigkeitsmonitoring: Migration von EU-Bürgern nach Deutschland, Jahresbericht 2016, Bundesamt für Migration und Flüchtlinge, Forschungszentrum Migration, Integration und Asyl, Nürnberg, 2017a, https://www.bamf.de/SharedDocs/Anlagen/ DE/Publikationen/Broschueren/freizuegigkeitsmonitoring-jahresbericht-2016. pdf?_blob=publicationFile 
Freizügigkeitsmonitoring: Migration von EU-Bürgern nach Deutschland, Bericht für das erste Halbjahr 2017, Bundesamt für Migration und Flüchtlinge, Forschungszentrum Migration, Integration und Asyl, Nürnberg, 2017b, https:/www.bamf.de/ SharedDocs/Anlagen/DE/Publikationen/Broschueren/freizuegigkeitsmonitoringhalbjahresbericht-2017.pdf?_blob=publicationFile

Höhe des durchschnittlichen Nettolohns/ Nettogehalts im Monat je Arbeitnehmer in Deutschland von 1991 bis 2016, STATISTA, Hamburg, 2017a, https:/de.statista.com/statistik/daten/ studie/370558/umfrage/monatliche-nettoloehne-und-gehaelter-je-arbeitnehmer-indeutschland/

Main countries of citizenship and birth of the foreign foreign-born population, 1 January 2016, Eurostat, http://ec.europa.eu/eurostat/statistics-explained/index. php/File:Main_countries_of_citizenship_and_birth_of_the_foreign_foreignborn_population,_1_January_2016_(\%C2\%B9)_(in_absolute_numbers_and_as_a_ percentage_of_the_total_foreign_foreign-born_population).png

Mehr als 10 Millionen Ausländer in Deutschland, Pressemitteilung Nr. 227, 30.06.2017, Statistisches Bundesamt (Destatis), Wiesbaden, 2017, https://www.destatis.de/DE/ PresseService/Presse/Pressemitteilungen/2017/06/PD17_227_12521.html

Migracija stanovništva Republike Hrvatske u 2016., Priopćenje 7.1.2, Državni zavod za statistiku, Zagreb, 2017, https://www.dzs.hr/Hrv_Eng/publication/2017/07-01-02_01_ 2017.htm

Popis stanovništva, kućanstava i stanova 2011. godine, Državni zavod za statistiku, Zagreb, 2012.

Statističke informacije 2016., Državni zavod za statistiku, Zagreb, 2016, https://www.dzs. hr/Hrv_Eng/StatInfo/pdf/StatInfo2016.pdf

Statistike u nizu, Migracije, Državni zavod za statistiku, Zagreb, 2017, https://www.dzs. $\mathrm{hr} / \mathrm{hrv} /$ publication/firstrelease/firstrel.asp

Statistiken zum Durchschnittseinkommen in Deutschland, STATISTA, Hamburg, 2017b, https:/de.statista.com/themen/293/durchschnittseinkommen/ 


\section{Contemporary Emigration of Croats to Germany: Motives and Characteristics}

\section{Tado Jurić}

SUMMARY

This article presents the first study of the characteristics and motives behind recent immigration of Croats to the Federal Republic of Germany. The article shows that, based on the perception of the emigrants themselves, the main motives for emigration are not economic.

The main objective of the research was to identify the motivation of Croats for emigration to Germany and to outline the reasons for emigration. The survey was conducted in the Federal Republic of Germany using mixed methodology. The data were collected using the survey and semi-structured interviews on a convenience sample of 1200 adult Croats who emigrated to Germany during the last four years. As a starting point, the official statistical data of Croatia and Germany were used in the analysis, serving as a descriptive and comparative framework of the study. The data were collected from February to November 2017. The data were collected through the network of Croatian teaching in Germany, the network of Croatian Catholic missions in Germany and the Facebook group "Idemo u svijet - Njemačka" (Let's go Abroad - Germany). The analysis of immigrant attitudes has shown that the main incentive for emigration is the idea that the values of work ethic and honesty are not institutionalised in Croatia. The immigrants' perception is that Croatian society is morally shattered. This research points to a very clear link between political ethics, weak institutions, and emigration. In addition to that, the existence of spreadout Croatian migrant networks in Germany from the past facilitates and encourages migration. It can be seen that the number of immigrants in Germany is higher than the number recorded by official statistics, and that main trends in emigration are the following: the emigration of young people between the age of 20 and 40 who were mostly employed, and the ones who have migrated with their entire families. The respondents reported high levels of satisfaction with their "new life" in Germany and have no regrets as to their emigration to Germany. Therefore, they rarely consider returning.

The results of the study have shown that the push factors from the country of origin are stronger than the pull factors in Germany. Most people claim to have lost trust in their homeland as well as the belief that Croatian society will succeed in becoming a healthy society in short to medium term.

There are also structural causes of emigration which are based on an inadequate model of centralised economy and inherited uneven distribution of population that originates from the former Socialist Federal Republic of Yugoslavia and the Croatian authorities' past negligence to correct that model. For most respondents, the culprits for the current situation and mass emigration of young people from the country are incompetent politicians, the inefficient judicial system, and war profiteering. The immorality of political elites, legal insecurity, nepotism, and corruption are at the top of the list of the motives that have contributed to emigration. 
We have noticed that young Croats did not leave for money. Richness is not the key value for any of them. In fact, in Germany they are willing to give up more, become more tolerant, and endure more than in their homeland simply because they believe that this will be adequately rewarded in Germany, whereas they have lost all trust in their homeland.

The study results also confirmed what the media speculated: today, highly educated, employed and married people are much more inclined to migrate, which was not the case in previous migrations. The dominant feature of this emigrant wave is the emigration of entire families, which was also a rare case in previous migrations to Germany. The greatest propensity for migration is found in people aged $25-40-$ the most productive part of society. In a sample of 1200 respondents, they make up $58.33 \%$.

Most of the emigrants are employed and most of them have completed high school $(60.7 \%)$, while the share of highly educated is $37.8 \%$. The share of highly educated persons in the emigrant contingent for the past three years is thus $12 \%$ higher than in the homeland, within the age group of 25-40. As for the regional attribution of the respondents, the greatest tendency for migration is expressed by the respondents from Zagreb and the surrounding area, as well as from Slavonia and Baranja (60\% of all migrants are from these regions).

The set of questions that checks emotional attitudes shows that the majority feel "generally better" than in their homeland, that nostalgia is not a prevailing emotion (as is often the case of Croatian discourse on migrants), and that the vast majority feel that in Germany they are getting more, in subjective and objective sense of the notion, than they are losing in the homeland. The research also disproves the thesis that Croatian emigrants work harder in Germany than in their homeland, as well as the widespread prejudice that Croatian migrants in Germany feel alienated and have a strong self-awareness of the fact that they are foreign.

Even though it was certainly not possible to examine the entire spectrum of motives and incentives for emigration, the ground has been set for further research of this important subject.

KEY WORDS: emigration, Croats, Croatia, Bosnia and Herzegovina, Germany 
